Research Article/Araştırma Makalesi

\title{
Determination of Digital Dependency Levels and Violence Tendencies of the High School Students
}

\author{
Aysel ARSLAN *1 \\ ${ }^{1}$ Sivas Cumhuriyet University, Vocational School of Health, Sivas, Turkey, arslanaysel.58@gmail.com \\ * Corresponding Author: arslanaysel.58@gmail.com
}

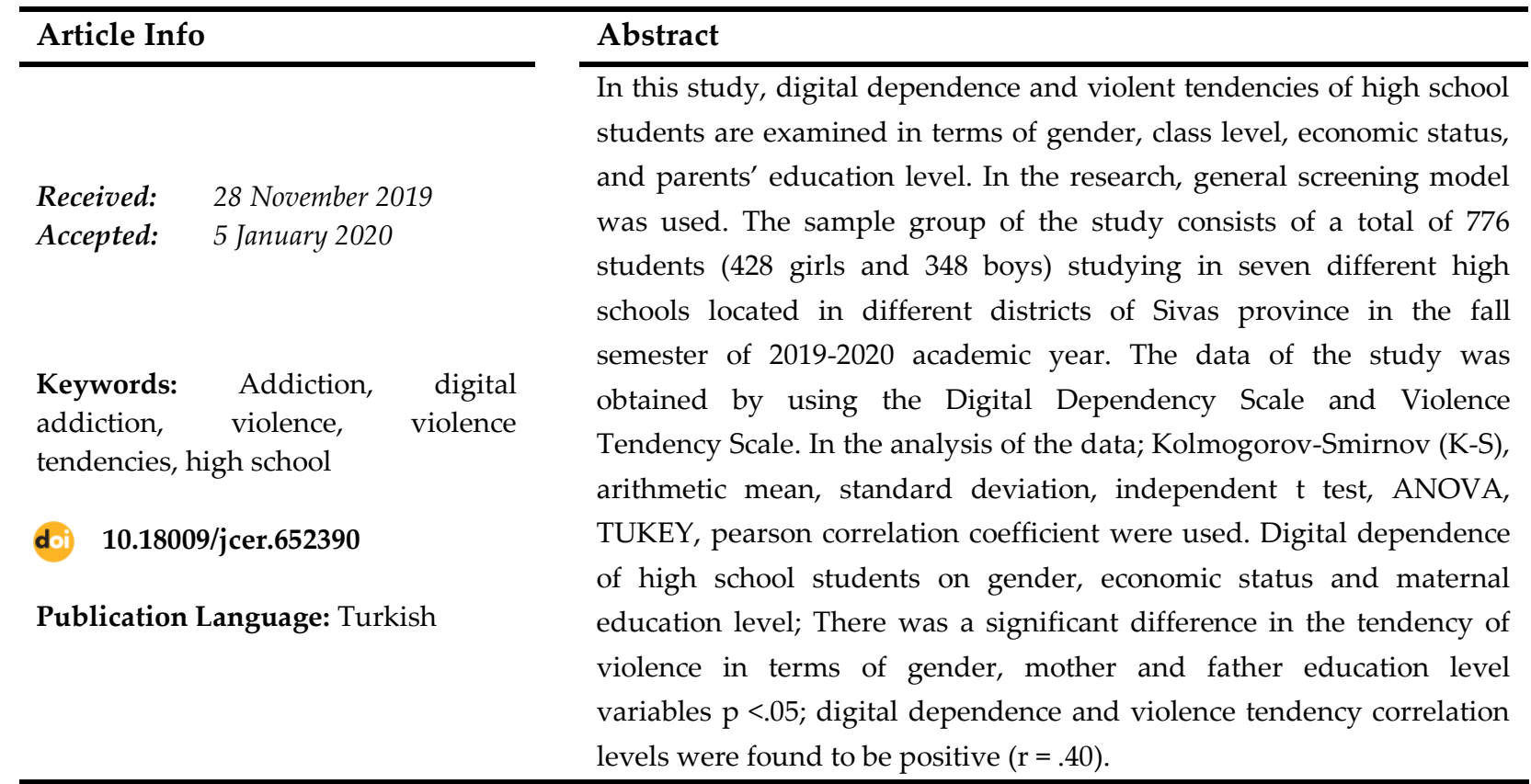
dijital bağımlılık düzeyleri ve şiddet eğilimlerinin belirlenmesi. Journal of Computer and Education Research, 8 (15), 86-113. DOI:10.18009/jcer.652390

\section{Ortaöğretim Öğrencilerinin Dijital Bağımlılık Düzeyleri ve Şiddet} Eğilimlerinin Belirlenmesi

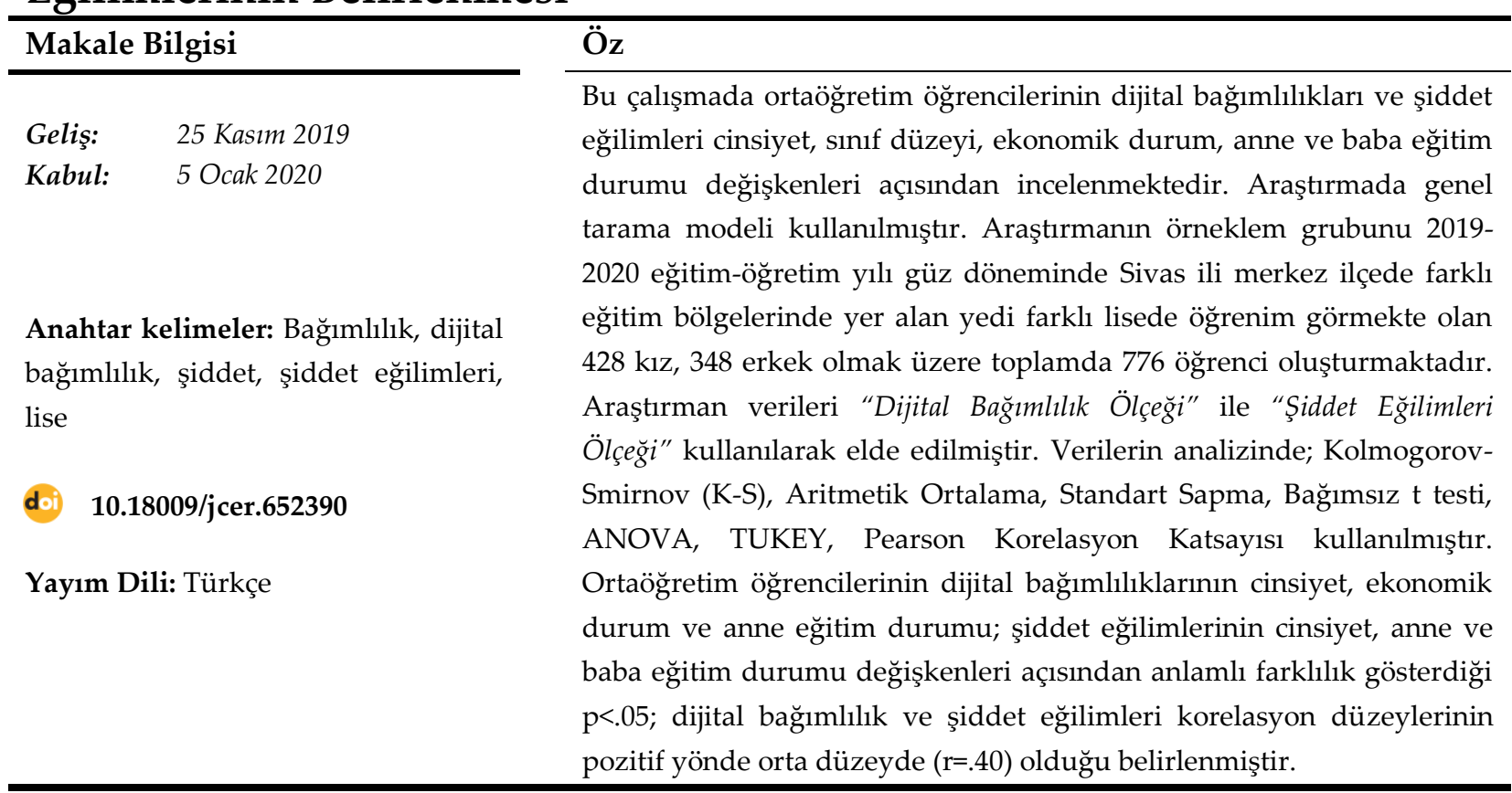




\section{Summary}

\section{Determination of Digital Dependency Levels and Violence Tendencies of the High School Students}

\section{Introduction}

It is seen that, technology is in every field of life especially the internet which enabling the general communication and developing for this reason the using of tools and equipment increases rapidly. In this direction, it is seen that the internet connection, digital tools and equipment make life easier for people. On the other hand, it is stated that besides the positive aspects of internet and digital tools and equipment, unwanted negative aspects also emerge. The most important of these negative situations is expressed as digital dependency. Although the person does not use any stuff, the habits causing negative behaviors observed in drug users are defined as behavioral dependence. Excessive desire to perform behaviors such as gambling, sex, eating, kleptomania, uncontrolled use of digital tools, using seamless social networking are considered as behavioral dependence.

Digital dependency, which is among the types of behavioral dependency, initially called internet addiction, as a result of the proliferation of tools and equipment that are connected to the internet and social platforms; it is divided into different categories such as smartphone, tablet, social media and game addiction. People who experience digital dependence constantly disrupt their communication with their environment because they prefer environments in which they can be alone and this person accepts a perception of virtual reality created by breaking away from real life. With the rapid spread of technology that can be connected to the internet network from anywhere with digital tools; connecting to social media from everywhere and from any environment, especially makes the children vulnerable to abuse. An important part of the games played in the digital environment contains violence and aggression. This situation, causes normalization of violence and aggression, on children and young people, playing these games. It is stated that the persons who shows individual violence behavior; these people have serious problems that they cannot solve especially during adolescence; they were not understood and supported by their family, school and environment and these people tend to violent acts as they are 
excluded because of their negative attitudes and behaviors. In adolescents who experience digital depence; the tendency to violence is thought to be higher than people who not experience addiction. In this study, it is aimed to determine the level of digital dependence and, violence tendencies, relationship level and direction between of them, among the high school students. Digital dependence and violence tendencies of high school students; in terms of gender, class level, economic status, mother and father education variables, was examed.

\section{Method}

The sample of this study consists of 776 students who continue their education in seven different high schools where located in the central district of Sivas province in different education regions, in 2019-2020 academic year fall semester. Simple random sampling method, which is among the general screening models, was used. The data of the research; It was obtained by using; "Digital Dependency Scale" which developed by Arslan et al. (2015); and "Trends of Violence Scale" which developed by Haskan and Yildirım (2012). SPSS 25.0 statistical program was used in the analysis of the obtained data. The data of the research; was obtained by using Kolmogorov-Smirnov (K-S) Test, One-Way analysis of variance (ANOVA), independent groups $t$ test, TUKEY analysis and Pearson Coefficient of Correlation test.

The digital dependence of the students was found to be moderate in the total scale and all the factors and it was determined that the violence tendency of the students was moderate in total score and all factors. According to the gender variable, it was determined that students' digital dependency, the mean score of the scale, the effect of daily life showed a significant difference against the male students and the game factor against the female students. The average score for the violent tendencies of the students; total score and all factors; It was determined that there is a significant difference against male students. Students' levels of digital dependence and violence tendencies; in terms of class level variable; It was found that there was no significant difference in the total of the scale and all factors.

\section{Result}

In terms of students' economic status variable, the mean of digital dependence score; the total of the scale, game and daily life effect factors differ significantly; however, there was no significant difference in social media factor. It was found that there was no significant 
difference on the tendency of violence, the variables of economic status in the total scale and all the factors, on the mean scores of the students. When the findings of the analysis of the students' digital dependency according to the variables of mother's educational status were examined; in the meaning of total scale, in terms of game and social media factors; It was determined that no significant difference but it was determined that there is a significant difference in the meaning of effect on daily life. The average score of students' violence tendency scale; in the meaning of total scale, violence with information technologies, violence against others; It was determined that were significant differences but it was found that there was no significant difference in feelings of violence and thought of harm to others. Digital dependence of the students in terms of father education status variable; It was found that there was no significant difference in terms of total scale and all factors. It was found that the mean scores of students' violent tendencies showed significant differences in terms of the total scale and the factor of violence against others and there was no significant difference in terms of other factors. It is seen that there is a moderate positive correlation between digital addiction levels and violence tendencies of students in terms of total scores and total factors. These results were interpreted that students with increased levels of digital addiction; it can be interpreted that their tendency towards violence has also increased.

\section{Conclusion}

Academicians, teachers, families and persons should be well-informed and conscious about digital dependency; and it is necessary to establish an effective control mechanism to determine the harmful effects of social media and tools. Limit access to harmful content on social media and the effective application of deterrent penalties related to cyber-crime elements, are thought to be important for the future of children and youth. Specialized treatment centers need to be established for the treatment of people experiencing digital addiction, with the professionals. In cooperation with educational institutions and health institutions; public awareness on this issue is very important. Researchers are not only directed to the negative effects seen today; It is considered that it is important to carry out studies on the dangers that may arise in the future to taking preventive measures. 


\section{Giriş}

Günümüz dünyasında teknoloji alanında yaşanan hızlı gelişim ve değişimler, bireylerin yaşamlarında da büyük değişimleri beraberinde getirmektedir. Teknolojinin hayatın her alanında olduğu, özellikle de yaygın iletişime olanak sağlayan internet ve buna bağlı olarak gelişen araç ve gereçlerin kullanımının hızla arttığı görülmektedir (Yen, Yen, Chen, Chen, \& Ko, 2007). Yaygın iletişim ağı olan internetin temel kullanım amacı; iletişim kurmak, araştırma yapmak, bilgi, edinmek, ticari faaliyetlerde bulunmak, eğlenmek olarak ifade edilmektedir (Seo, Kong, \& Yom, 2009). Bu doğrultuda internet bağlantısı, dijital araç ve gereçlerin bireylerin hayatını oldukça kolaylaştırdı̆̆ı görülmektedir. Ancak internet, dijital araç ve gereçler kullanılmaya başlandıktan sonra tüm bu olumlu yanlarının yanı sıra istenmeyen olumsuz yanlarının da ortaya çıktığı belirtilmektedir. Bu olumsuz durumların en önemlisi dijital bağımlılık olarak ifade edilmektedir (Sparrow \& Griffiths, 1997).

Genelde fiziksel bir maddeye yönelik olarak bireylerin duyduğu kontrol edilemeyen derecede yüksek istek olarak tanımlanan bağımlılık kavramı (Holden, 2001); maddeye yönelik bağımlılık ve davranışa yönelik bağımlılık olmak üzere iki ana başlık altında incelenmektedir. Bireyin alkol, sigara, uyuşturucu özelliği olan katı, sıvı ve uçucu maddeleri sürekli kullanmak için duyduğu istek, bastıramadığı dürtü madde bağımlılı̆̆ı olarak tanımlanmaktadır (Kurupınar \& Erdamar, 2014: 66). Bireyin herhangi bir madde kullanmamasına karşın madde kullananlarda gözlenen olumsuz davranışların ortaya çıkmasına neden olan alışkanlıklar davranışsal bağıımlılık olarak tanımlanmaktadır (Sevindik, 2011: 10). Birey, sürekli olarak bağımlısı olduğu davranışı düşünmekte ve bu davranışı gerçekleştirmek için büyük bir istek duymaktadır. Davranışı yapamadığı ortam ve durumlarda ise çevresine yönelik tolerans düzeyinde belirgin düşmeler, duygularında tutarsızlıklar, yoksunluk davranışları gözlenmektedir. Kumar, seks, yemek yeme, kleptomani (çalma hastalığı), kontrolsüz bir şekilde dijital araçları kullanma, sosyal ağlardan kopamama vb. davranışları yapmaya yönelik aşırı istek davranışsal bağımlılık olarak değerlendirilmektedir (Griffths, 1999). Marks (1990), görülen bazı farklılıklar nedeniyle davranışsal bağımlılı̆̆ın madde bağımlılı̆̆ından ayrıldığını belirtmektedir. Bu farklılıkların başlıcalarının ise; bireyin herhangi bir madde kullanmaması, zihninin sürekli bağımlı olduğu davranışla meşgul olması sonucunda sosyal hayata yönelik algılarının zayıflaması, daha çok tek bir davranışa yönelik aşııı istek duyulması, takıntılı davranışların sergilenmesi, tedavi 
sürecinin madde bağımlılı̆̆ına göre daha kısa sürmesi ve yapılan tedavilerden yüksek oranda olumlu sonuçların alınması olduğunu söylemektedir.

Davranışsal bağımlılık türleri içinde yer alan dijital bağımlılık, başlangıçta internet bağımlılığı olarak adlandırılsa da günümüzde internetle bağlantısı olan araç ve gereçlerin, sosyal platformların çoğalması sonucunda akıllı telefon, tablet, sosyal medya, oyun bağımlılığı gibi farklı kategorilere ayrılmaktadır. Dijital bağımlılığın dünya genelinde çok hızlı bir şekilde yaygınlaştığı, bireyin günlük yaşantısı ve sağlığı üzerinde pek çok olumsuz sonuç doğurduğu belirtilmektedir (Arslan, Kırık, Karaman, \& Çetinkaya, 2015). Kişiliğin gelişmesi için gerekli sosyal ortamlarda bulunmayan bireyde sosyal beceriler de olgunlaşmadığı için kişilik bozuklukları görülmektedir (Shine \& Beak, 2013). Ayrıca ilerleyen süreçte de şu anda bilinmeyen veya tanısı tam olarak konulamayan farklı zararlı etkilerinin de ortaya çıkabileceği ifade edilmektedir (Vural \& Bat, 2010: 321). Dijital araç-gereçlerle internet ağına her yerden bağlanabilen teknolojinin hızla yaygınlaşmasıyla her yerden ve ortamdan sosyal medyaya bağlanılması özellikle küçük yaşlardaki çocukları istismara açık hale getirmektedir. Sahte kimlik ve hesaplar üzerinden zorbalık, saldırı ve şiddet davranışları sergilenmektedir. Sosyal ağlarda paylaşılan resimler ve bilgiler kullanılarak dolandırıcılık ve şantaj olayları yaşanmaktadır (Doğan \& Tosun, 2016). İnternet ağıyla bağlantı kurulan dijital platformların güvenlik denetimlerinin yetersiz olması da başka sorunları berberinde getirmektedir (Vural \& Bat, 2010: 321).

Teknolojinin yaygınlaşmasına paralel olarak tüm dünyada ve ülkemizde şiddetin özellikle küçük yaştaki çocuklar ve gençlerde yaygınlaştı̆̆ı belirtilmektedir. Çocuklar ve gençler şiddetin hem uygulayıcısı hem de mağduru olmaktadır. Dijital ortamlarda oynanan oyunların önemli bir kısmının şiddet ve saldırganlık içermektedir. Bu durum oyunları oynayan çocuklar ve gençler üzerinde şiddet ve saldırganlığın normalleşmesine zemin hazırlamaktadır (Erkek, 2016: 22). Bilerek farklı şekillerde zarar vermek, hak ihlalinde bulunmak, kaba kuvvet sergilemek vb. davranışları içermektedir (Dursun, 2011). Bireyin saldırganca davranışının sonucunda bir veya daha fazla sayıdaki kişinin fiziksel veya psikolojik bütünlüğü bozulmaktadır (İldeş, 2002). Birey veya toplumlarda görülen şiddet eğilimlerinin artmasında farklı etkenler öne sürülmektedir. Bu etkenlerin başlıcaları; yaşanılan dönemdeki savaşlar, afetler, kültürel zorunluluklar olduğu ifade edilmektedir. Aslında bunlar bireyin kontrol edemediği risk faktörleri olarak tanımlanmaktadır. Bu risk 
faktörleri şiddet süresi, derinliği, yoğunluğu, boyut ve türünü belirlemektedir (Page \& İnce, 2008).

Bireysel olarak şiddet davranışları gösteren bireylerin özellikle ergenlik döneminde çözümleyemediği ciddi sorunlar yaşadığı, aile, okul ve çevresi tarafından anlaşılarak destek görmediği gibi sürekli olumsuz tutum ve davranışları yüzünden dışlandığı için şiddet eylemlerine yöneldiği belirtilmektedir (Dahlberg \& Potter, 2001). Bu eylemlerin genellikle bireyin ergenlik dönemiyle sınırlı kalmadığı, bu dönemde yerleşen tutum ve davranışların yetişkinlik sürecinde de devam ettiği ifade edilmektedir. Ergenlik döneminde şiddete yönelen bireylerin toplumsal dışlanmadan dolayı antisosyal kişilik yapısı gösterdiği, sosyal ortamlardan koparak suç odaklı gruplarla bağlantı kurma eğilimde oldukları belirtilmektedir (Williams \& Myers, 2004). Ergenlik döneminde ortaya çıkan şiddet davranışları özellikle okul ortamında daha belirgin olarak gözlenmektedir (Dahlberg \& Potter, 2001). Okulda gözlemlenen şiddet davranışları sınıf veya okul içi ile sınırlı olmayıp okul türüne göre yatakhane, servis araçları, yemekhane, okul bahçesi vb. alanlarda da gözlenmektedir (Williams \& Myers, 2004). Okul yöneticilerinin ve öğretmenlerin öğrencilerde gözlemledikleri olumsuz davranışlar karşısında nasihat etmek, görüşmek, uyarmak gibi bireysel veya rehberlik servislerinden, diğer öğretmenlerden ve velilerden yardım istemek şeklinde çözüm stratejileri kullandıkları görülmektedir (Arslan, 2018: 75).

Bireyin çocukluk, ergenlik ve yetişkinlik dönemlerinde farklı nedenlerle ortaya çıkan şiddet davranışlarının nedenlerinin belirlenmesi gerekmektedir. Bu nedenlerin belirlenmesi hem bireyin şiddet davranışından vazgeçebilmesi için gerekli desteğin doğru bir şekilde verilmesinde hem de toplumun bireyi davranışlarına tepki olarak dışlamasının önüne geçilmesinde oldukça önemli olmaktadır. Gerekli desteği bulamayan ve toplumdan dışlanan bireylerin gittikçe yalnızlaştığı ve gerek kendisine gerekse diğer insanlara yönelik olarak daha fazla şiddet davranışı gösterdiği ifade edilmektedir. Bireyin şiddet davranışının önüne geçmek için çözüm odaklı çalışmaların ortaya konulması gerekmektedir (Davey, Day, \& Howells, 2005). Dijital bağımlılık yaşayan ergenlik dönemindeki bireylerde şiddete eğilim oranının bağımlılık yaşamayan bireylere göre daha fazla olduğu düşünülmektedir. Bunun gerekçesi olarak; bireylerin yaşadıkları bağımlılık dolayısıyla diğer bireylerle normal iletişim kurmakta zorlanmaları, özellikle sanal oyunlardaki şiddet unsurlarını kanıksayarak gerçek hayatta da bunu normal olarak algılamaları, toplumdan kendilerini soyutladıkları için gördükleri tepkiler karşısında şiddete yönelmeleri gösterilmektedir. 
$\mathrm{Bu}$ çalışmada lise düzeyinde eğitim alan gençlerin dijital bağımlılık düzeylerinin ve şiddete yönelik eğilimlerinin belirlenmesi, aralarındaki ilişki düzeyi ve yönünün saptanması amaçlanmaktadır. Bu çalışmanın ilgili alan yazına katkı sağlayacağı düşünülmektedir. Bu amaçla lise öğrencilerine uygulanan ölçekler aracılığıyla aşağıdaki soruların yanıtları aranmıştır:

a) Ortaöğretim öğrencilerinin dijital bağımlılık düzeyleri ve şiddet eğilimlerine ilişkin puan ortalamaları ölçeğin tamamında ve alt boyutlarında hangi düzeydedir?

b) Ortaöğretim öğrencilerinin dijital bağımlılık düzeyleri cinsiyet, sınıf düzeyi, ekonomik durum, anne eğitim durumu ve baba eğitim durumu değişkenlerine göre anlamlı şekilde farklılaşmakta mıdır?

c) Ortaöğretim öğrencilerinin şiddet eğilimleri cinsiyet, sınıf düzeyi, ekonomik durum, anne eğitim durumu ve baba eğitim durumu değişkenlerine göre anlamlı şekilde farklılaşmakta midır?

\section{Yöntem}

Bu araştırmanın örneklemini 2019-2020 eğitim-öğretim yılı güz döneminde Sivas ili merkez ilçede farklı eğitim bölgelerinde bulunan yedi farklı lisede öğrenimlerine devam eden 428 kız, 348 erkek olmak üzere toplamda 776 öğrenci oluşturmaktadır. Araştırmaya katılan öğrencilere araştırma hakkında genel bilgilendirme yapılmış ve gönüllülük esasına riayet edilmiştir. Genel tarama modelleri arasında yer alan basit seçkisiz örnekleme yönteminin kullanıldığı bu araştırmaya dâhil edilen katılımcılara ilişkin betimsel istatistikler Tablo 1'de sunulmaktadır.

Tablo 1. Örneklem grubuna ilişkin betimsel özellikler

\begin{tabular}{llcl}
\hline Değişkenler & & (f) & (\%) \\
\hline \multirow{2}{*}{ Cinsiyet } & Kız & 428 & 55.15 \\
& Erkek & 348 & 44.85 \\
\hline \multirow{3}{*}{ Sınıf düzeyi } & 9. Sınıf & 281 & 36.21 \\
& 10. Sınıf & 198 & 25.52 \\
& 11. Sınıf & 168 & 21.65 \\
& 12. Sınıf & 129 & 16.62 \\
\hline \multirow{2}{*}{ Ekonomik durum } & Çok İyi & 91 & 11.73 \\
& İyi & 280 & 36.08 \\
\hline \multirow{3}{*}{ Anne eğitim durumu } & Orta & 343 & 44.20 \\
& Düşük & 62 & 7.99 \\
\hline \multirow{3}{*}{ Baba eğitim durumu } & İlkokul & 305 & 39.30 \\
& Ortaokul & 227 & 29.25 \\
& Lise & 158 & 20.36 \\
& Üniversite & 86 & 11.08 \\
\hline
\end{tabular}


Tablo 1'deki bulgulara bakıldığında; araştırmaya dâhil edilen öğrencilerin \%55.15'nin k1z, \%45.85'nin erkek olduklar1; \%36.21'inin dokuzuncu, \%25.52'sisnin onuncu, \%21.65'inin on birinci, \%16.62'sinin on ikinci sınıfta öğrenimlerine devam ettikleri görülmektedir. Öğrencilerin ailelerinin ekonomik durumlarının ağırlıklı olarak iyi ve orta düzeyde olduğu; anne eğitim durumlarının ilkokul ve ortaokulda yoğunlaşırken baba eğitim durumlarının lisede yoğunlaştı̆̆1 ve diğer eğitim kademelerinde birbirine yakın olduğu belirlenmiştir.

\section{Veri Toplama Araçları}

Araştırmaya ilişkin veriler; Arslan vd. (2015) tarafından geliştirilen “Dijital Bağımlılık Ölçeği” ile Haskan ve Yıldırım (2012) tarafından geliştirilen "Şiddet Eğilimleri Ölçeği” kullanılarak elde edilmiştir.

\section{Dijital Bă̆ımlılık Ölçeği}

Arslan vd. (2015) tarafından ortaöğretim öğrencileri düzeyinde kullanılmak üzere geliştirilen “Dijital Bağımlılık Ölçeği”; “Oyun” (11 madde), "Sosyal Medya” (12 madde), “Günlük Hayata Etkisi” (6 madde) olmak üzere üç alt faktör ve toplamda 29 maddeden oluşmaktadır. Bu araştırmada ölçeğin güvenirliği oyun faktöründe .90 , medya faktöründe .90, günlük hayata etkisi faktöründe .87 ve toplamda .92 olarak belirlenmiştir. Ölçek beşli likert tipinde hazırlanmış olup "Kesinlikle Katılmıyorum=1" ile "Tamamen Katılıyorum=5" arasında derecelendirilmiştir. Ölçek uygulamasından alınabilecek en yüksek puan 145 en düşük puan ise 29'dur. Öğrencilerin ölçek uygulamasından aldıkları puan ortalamaları yükseldikçe dijital bağımlılık düzeylerinin arttığ1 düştükçe azaldığı şeklinde çıkarımda bulunulabilir.

\section{Şiddet Eğilimleri Ölçeği}

Haskan ve Yıldırım'ın (2012) geliştirdiği "Şiddet Eğilimleri Ölçeği”; "Şiddet Duygusu" (6 madde), "Bilişim Teknolojileri Aracılığıyla Şiddet” (4 madde), "Başkalarına Zarar Verme Düşüncesi" (5 madde) ve "Başkalarına Şiddet Uygulama" (5 madde) olmak üzere dört faktör ve 20 maddeden oluşmaktadır. Ölçek geliştirme çalışmasında toplam güvenirliği .87; bu çalışmada ise .88 olarak tespit edilmiştir. Ölçeğin faktörlerinde güvenirliği; şiddet duygusu faktöründe .80, bilişim teknolojileri aracılığıyla şiddet faktöründe .71 başkalarına zarar verme düşüncesi faktöründe .79, başkalarına şiddet uygulama faktöründe .76 olarak belirlenmiştir. Üçlü likert tipinde hazırlanan ölçek “Hiçbir 
zaman=1", "Bazen=2" ve "Her zaman=3" şeklinde derecelendirilmiştir. Ölçek uygulaması sonucunda alınabilecek en yüksek puan 60, en düşük puan ise 20 olmaktadır.

\section{Verilerin Toplanması ve Analizi}

Araştırma verilerinin elde edilmesi amaciyla Sivas il merkezinde bulunan farklı eğitim bölgelerinde bulunan yedi farklı lise belirlenerek uygulama için gerekli izinler alınmıştır. 2019-2020 eğitim-öğretim yılı güz döneminde 428 kız, 348 erkek olmak üzere 776 öğrenciye ölçekler uygulanmıştır. Uygulamada öğrenci gönüllülüğü ilkesine riayet edilmiştir. Elde edilen verilerin analizinde SPSS 25.0 istatistik programı kullanılmıştır. Puanların normal dağılıp dağılmadı̆̆ının belirlenmesi amacıyla Kolmogorov-Smirnov (K-S) Testi uygulanmıştır. Verilerin normallik değerlerini karşıladığı belirlenmiştir. Öğrencilerin dijital bağımlılıkları ve şiddet eğilimlerinin cinsiyet, sınıf düzeyi, ekonomik durum, anne eğitim durumu ve baba eğitim durumu değişkenleri açısından anlamlı farklılık gösterip göstermediğinin tespiti amacıyla tek yönlü varyans analizi (ANOVA) ve bağımsız gruplar $\mathrm{t}$ testi uygulanmıştır. Yapılan ANOVA testinde anlamlı farklılık olduğu belirlenen gruplarda anlamlı farklılı̆̆ın hangi gruplar arasında olduğunun tespiti amaciyla TUKEY analizi uygulanmıştır. Öğrencilerin dijital bağımlılık düzeyleri ile şiddet eğilimleri arasındaki ilişkiler pearson korelasyon katsayısı ile analiz edilmiştir.

\section{Bulgular}

$\mathrm{Bu}$ çalışma kapsamında elde edilen verilerin analiz edilmesi sonucunda elde edilen bulgular, araştırma sorularının sırasına uygun olarak aşağıda sunulmaktadır. Ortaöğretim düzeyinde eğitim gören öğrencilerin şiddet eğilimleri ölçeğinin tamamından ve toplamından aldıkları puan ortalamaları Tablo 2' de sunulmaktadır.

Tablo 2. Ölçeklere ilişkin betimsel istatistikler

\begin{tabular}{lcccccc}
\hline Ölçekler & $\mathbf{N}$ & $\begin{array}{c}\text { En düşük } \\
\text { puan }\end{array}$ & $\begin{array}{c}\text { En yüksek } \\
\text { puan }\end{array}$ & $\overline{\mathbf{X}}$ & $\begin{array}{c}\text { Madde } \\
\text { ort. }\end{array}$ & ss \\
\hline Toplam puan & 776 & 29 & 145 & 81.99 & 2.83 & 22.34 \\
$\quad$ Oyun & 776 & 11 & 55 & 28.45 & 2.59 & 10.60 \\
$\quad$ Sosyal medya & 776 & 12 & 60 & 37.28 & 3.11 & 10.96 \\
$\quad$ Günlük hayata etkisi & 776 & 6 & 30 & 16.26 & 2.71 & 6.24 \\
\hline Toplam puan & 776 & 20 & 59 & 36.33 & 1.82 & 7.95 \\
$\quad$ Şiddet duygusu & 776 & 6 & 18 & 10.35 & 1.73 & 2.86 \\
Bilişim şiddeti & 776 & 4 & 12 & 7.20 & 1.80 & 1.84 \\
Zarar verme düşüncesi & 776 & 5 & 15 & 8.84 & 1.77 & 2.48 \\
$\quad$ Şiddet uygulama & 776 & 5 & 15 & 9.94 & 1.99 & 2.44 \\
\hline
\end{tabular}


Tablo 2'deki veriler incelendiğinde; öğrencilerin dijital bağımlılık düzeylerinin ölçeğin toplamında orta düzeyde (2.83), oyun faktöründe orta düzeyde (2.59), sosyal medya faktöründe orta düzeyde (3.11), günlük hayata etkisi faktöründe orta düzeyde (2.71) olarak belirlenmiştir. Ortaöğretim öğrencilerinin dijital bağımlılık ölçeğinden aldıkları en yüksek puan ortalamasının sosyal medya en düşük puan ortalamasının ise oyun faktörüne ait olduğu görülmektedir. Öğrencilerin şiddet eğilimleri ise toplam puanda (1.82), şiddet duygusu faktöründe orta düzeyde (1.73), bilişim teknolojileri aracılığıyla şiddet faktöründe orta düzeyde (1.80), başkalarına zarar verme düşüncesi faktöründe orta düzeyde (1.77), başkalarına şiddet uygulama faktöründe orta düzeyde (1.99) olarak belirlenmiştir. Ortaöğretim öğrencilerinin şiddet eğilimleri ölçeğinden aldıkları puan ortalamalarına göre en yüksek puanı başkalarına şiddet uygulama faktöründe en düşük puanı ise şiddet duygusu faktöründe aldıkları görülmektedir.

Ortaöğretim öğrencilerinin dijital bağımlılık düzeylerinin ve şiddet eğilimlerinin cinsiyet değişkenine göre anlamlı şekilde farklılık gösterip göstermediğinin belirlenmesi amacıyla uygulanan bağımsız gruplar t testi bulgularına Tablo 3 'te yer verilmektedir.

Tablo 3. Cinsiyet değişkenine göre dijital bağımlılık ve şiddet eğilimleri bağımsız gruplar t testi bulguları

\begin{tabular}{|c|c|c|c|c|c|c|}
\hline & Cinsiyet & $\mathbf{N}$ & $\overline{\mathrm{X}}$ & ss & $\mathbf{t}$ & p \\
\hline \multirow{2}{*}{ Toplam } & $\mathrm{K}_{1 \mathrm{Z}}$ & 428 & 78.35 & 21.93 & \multirow{2}{*}{-5.12} & \multirow{2}{*}{$.000^{*}$} \\
\hline & Erkek & 348 & 86.48 & 22.04 & & \\
\hline \multirow{2}{*}{ Oyun } & $\mathrm{K}_{1 \mathrm{z}}$ & 428 & 25.38 & 9.88 & \multirow{2}{*}{-9.41} & \multirow{2}{*}{$.000^{*}$} \\
\hline & Erkek & 348 & 23.23 & 10.25 & & \\
\hline \multirow{2}{*}{ Sosyal medya } & $\mathrm{K}_{1 Z}$ & 428 & 37.23 & 11.48 & \multirow{2}{*}{-.15} & \multirow{2}{*}{.880} \\
\hline & Erkek & 348 & 37.35 & 10.29 & & \\
\hline \multirow{2}{*}{$\begin{array}{l}\text { Günlük hayata } \\
\text { etkisi }\end{array}$} & $\mathrm{K}_{1 \mathrm{z}}$ & 428 & 15.74 & 6.09 & \multirow{2}{*}{-2.57} & \multirow{2}{*}{$.010^{*}$} \\
\hline & Erkek & 348 & 16.90 & 6.36 & & \\
\hline \multirow{2}{*}{ Toplam } & $\mathrm{K}_{1 z}$ & 428 & 34.51 & 7.40 & \multirow{2}{*}{-7.26} & \multirow{2}{*}{$.000^{*}$} \\
\hline & Erkek & 348 & 38.57 & 8.03 & & \\
\hline \multirow{2}{*}{ Şiddet duygusu } & $K_{1 z}$ & 428 & 9.76 & 2.60 & \multirow{2}{*}{-6.60} & \multirow{2}{*}{$.000^{*}$} \\
\hline & Erkek & 348 & 11.07 & 3.00 & & \\
\hline \multirow{2}{*}{ Bilişim şiddeti } & $\mathrm{K}_{1 z}$ & 428 & 6.95 & 1.74 & \multirow{2}{*}{-4.19} & \multirow{2}{*}{$.000^{*}$} \\
\hline & Erkek & 348 & 7.50 & 1.90 & & \\
\hline \multirow{2}{*}{$\begin{array}{l}\text { Zarar verme } \\
\text { düşüncesi }\end{array}$} & $\mathrm{K}_{1 \mathrm{Z}}$ & 428 & 8.36 & 2.37 & \multirow{2}{*}{-6.02} & \multirow{2}{*}{$.000^{*}$} \\
\hline & Erkek & 348 & 9.42 & 2.49 & & \\
\hline \multirow{2}{*}{ Şiddet uygulama } & $\mathrm{K}_{1 \mathrm{Z}}$ & 428 & 9.44 & 2.31 & \multirow{2}{*}{-6.51} & \multirow{2}{*}{$.000^{*}$} \\
\hline & Erkek & 348 & 10.56 & 2.45 & & \\
\hline
\end{tabular}

${ }^{*} \mathrm{p}<.05$

Tablo 3'teki bulgulara göre öğrencilerin dijital bağımlılıkları puan ortalamalarının ölçeğin toplamı, günlük hayat etkisi faktöründe erkek, oyun faktöründe kız öğrencilerin 
aleyhine; şiddet eğilimlerine ilişkin puan ortalamalarının cinsiyet değişkeni açısından ölçeğin toplam puanı ve tüm faktörlerinde erkek öğrencilerin aleyhine olmak üzere anlamlı farklılık gösterdiği p<.05 belirlenmiştir. Dijital bağımlılık ölçeğinin sosyal medya faktöründe ise anlamlı farklılık $\mathrm{p}>.05$ belirlenememiştir.

Ortaöğretim öğrencilerinin dijital bağımlılık düzeylerine ilişkin puan ortalamalarının sınıf düzeyi değişkenine göre anlamlı şekilde farklılık gösterip göstermediğinin belirlenmesi amaciyla uygulanan ANOVA testi bulgularına Tablo 4'te yer verilmektedir.

Tablo 4. Sınıf düzeyi değişkenine göre dijital bağımlılıkları ANOVA testi bulguları

\begin{tabular}{|c|c|c|c|c|c|c|c|}
\hline & Sinif & $\mathbf{N}$ & $\bar{x}$ & ss & F & p & $\begin{array}{c}\text { Anlamlı Fark } \\
\text { TUKEY }\end{array}$ \\
\hline \multirow{4}{*}{ Toplam } & 9. Sinif & 281 & 82.65 & 22.45 & \multirow{4}{*}{.60} & \multirow{4}{*}{.618} & \multirow{4}{*}{ Yok } \\
\hline & 10. sinif & 198 & 81.05 & 20.91 & & & \\
\hline & 11. Sinif & 168 & 83.24 & 22.08 & & & \\
\hline & 12. Sinif & 129 & 80.39 & 24.55 & & & \\
\hline \multirow{4}{*}{ Oyun } & 9. Sinif & 281 & 28.26 & 10.19 & \multirow{4}{*}{.68} & \multirow{4}{*}{.565} & \multirow{4}{*}{ Yok } \\
\hline & 10. sinif & 198 & 29.33 & 10.25 & & & \\
\hline & 11. Sinif & 168 & 27.85 & 10.69 & & & \\
\hline & 12. Sinif & 129 & 28.29 & 11.87 & & & \\
\hline \multirow{4}{*}{$\begin{array}{l}\text { Sosyal } \\
\text { medya }\end{array}$} & 9. Sinif & 281 & 37.87 & 11.29 & \multirow{4}{*}{2.39} & \multirow{4}{*}{.068} & \multirow{4}{*}{ Yok } \\
\hline & 10. sinif & 198 & 35.83 & 9.72 & & & \\
\hline & 11. Sinif & 168 & 38.57 & 11.14 & & & \\
\hline & 12. Sinif & 129 & 36.57 & 11.59 & & & \\
\hline \multirow{4}{*}{$\begin{array}{l}\text { Günlük } \\
\text { hayata etkisi }\end{array}$} & 9. Sinif & 281 & 16.52 & 6.34 & \multirow{4}{*}{1.46} & \multirow{4}{*}{.224} & \multirow{4}{*}{ Yok } \\
\hline & 10. sinif & 198 & 15.88 & 5.80 & & & \\
\hline & 11. Sinif & 168 & 16.83 & 6.15 & & & \\
\hline & 12. Sinif & 129 & 15.53 & 6.70 & & & \\
\hline
\end{tabular}

Tablo 4 incelendiğinde ortaöğretim düzeyinde öğrenim gören öğrencilerin dijital bağımlılık düzeylerinin sınıf değişkeni açısından ölçeğin toplamı ve tüm faktörlerinde anlamlı farklılık oluşturmadığı p>.05 bulgusuna ulaşılmıştır. Toplam puan açısından değerlendirildiğinde en yüksek puan ortalamasına 11. sınıfta öğrenim gören öğrencilerin en düşük puan ortalamasına ise 12. sınıfta öğrenim gören öğrencilerin sahip oldukları tespit edilmiştir.

Ortaöğretim öğrencilerinin şiddet eğilimlerine ilişkin puan ortalamalarının sınıf düzeyi değişkenine göre anlamlı şekilde farklılık gösterip göstermediğinin belirlenmesi amaciyla uygulanan ANOVA testi bulgularına Tablo 5'te yer verilmektedir. 
Tablo 5. Sınıf düzeyi değişkenine göre şiddet eğilimleri ANOVA testi bulguları

\begin{tabular}{|c|c|c|c|c|c|c|c|}
\hline & Sinif & $\mathbf{N}$ & $\overline{\mathbf{X}}$ & ss & F & $\mathrm{p}$ & $\begin{array}{c}\text { Anlamlı Fark } \\
\text { TUKEY }\end{array}$ \\
\hline \multirow{4}{*}{ Toplam } & 9. Sinif & 281 & 35.81 & 7.74 & \multirow{4}{*}{1.38} & \multirow{4}{*}{.247} & \multirow{4}{*}{ Yok } \\
\hline & 10. sinif & 198 & 36.88 & 7.07 & & & \\
\hline & 11. Sinif & 168 & 37.02 & 8.01 & & & \\
\hline & 12. Sinif & 129 & 35.74 & 9.41 & & & \\
\hline \multirow{4}{*}{$\begin{array}{l}\text { Şiddet } \\
\text { duygusu }\end{array}$} & 9. Sinif & 281 & 10.18 & 2.82 & \multirow{4}{*}{1.17} & \multirow{4}{*}{.321} & \multirow{4}{*}{ Yok } \\
\hline & 10. sinif & 198 & 10.57 & 2.63 & & & \\
\hline & 11. Sinif & 168 & 10.55 & 2.81 & & & \\
\hline & 12. Sinif & 129 & 10.16 & 3.32 & & & \\
\hline \multirow{4}{*}{$\begin{array}{l}\text { Bilişim } \\
\text { şiddeti }\end{array}$} & 9. Sinif & 281 & 7.07 & 1.84 & \multirow{4}{*}{.97} & \multirow{4}{*}{.408} & \multirow{4}{*}{ Yok } \\
\hline & 10. sinif & 198 & 7.31 & 1.75 & & & \\
\hline & 11. Sinif & 168 & 7.32 & 1.81 & & & \\
\hline & 12. Sinif & 129 & 7.13 & 2.00 & & & \\
\hline \multirow{4}{*}{$\begin{array}{l}\text { Zarar verme } \\
\text { düşüncesi }\end{array}$} & 9. Sinif & 281 & 8.60 & 2.36 & \multirow{4}{*}{2.75} & \multirow{4}{*}{.042} & \multirow{4}{*}{ Yok } \\
\hline & 10. sinif & 198 & 9.08 & 2.30 & & & \\
\hline & 11. Sinif & 168 & 9.13 & 2.58 & & & \\
\hline & 12. Sinif & 129 & 8.58 & 2.81 & & & \\
\hline \multirow{4}{*}{$\begin{array}{l}\text { Şiddet } \\
\text { uygulama }\end{array}$} & 9. Sinif & 281 & 9.95 & 2.49 & \multirow{4}{*}{.11} & \multirow{4}{*}{.956} & \multirow{4}{*}{ Yok } \\
\hline & 10. sinif & 198 & 9.92 & 2.26 & & & \\
\hline & 11. Sinif & 168 & 10.02 & 2.31 & & & \\
\hline & 12. Sinif & 129 & 9.86 & 2.75 & & & \\
\hline
\end{tabular}

Tablo 5'teki verilere göre ortaöğretim düzeyinde eğitim alan öğrencilerin şiddet eğilimlerinin sınıf düzeyi değişkeni açısından ölçeğin toplamı ve tüm faktörlerinde anlamlı farklılık göstermediği p >.05 tespit edilmiştir. Toplam puan açısından bakıldığında en yüksek puanın on birinci sınıf öğrencilerine en düşük puanın ise on ikinci sınıf öğrencilerine ait olduğu görülmektedir. Ortaöğretim öğrencilerinin dijital bağımlılık puan ortalamalarının ekonomik durum değişkenine göre anlamlı şekilde farklılık gösterip göstermediğinin belirlenmesi amaciyla uygulanan ANOVA testi bulgularına Tablo 6' da yer verilmektedir.

Tablo 6. Ekonomik durum değişkenine göre dijital bağımlılık ANOVA testi bulguları

\begin{tabular}{|c|c|c|c|c|c|c|c|}
\hline & Ekon. Dur. & $\mathbf{N}$ & $\overline{\mathrm{x}}$ & ss & $\mathbf{F}$ & $\mathbf{p}$ & $\begin{array}{c}\text { Anlamli Fark } \\
\text { TUKEY }\end{array}$ \\
\hline \multirow{4}{*}{ Toplam } & 1.Çok İyi & 91 & 81.69 & 19.60 & \multirow{4}{*}{3.06} & \multirow{4}{*}{$.027^{*}$} & \multirow{4}{*}{$\begin{array}{l}4 \text { ile } 2,3 \\
\text { arasında }\end{array}$} \\
\hline & 2.İyi & 280 & 81.17 & 21.41 & & & \\
\hline & 3. Orta & 343 & 81.27 & 23.33 & & & \\
\hline & 4.Düşük & 62 & 90.19 & 23.43 & & & \\
\hline \multirow{4}{*}{ Oyun } & 1.Çok İyi & 91 & 28.34 & 9.31 & \multirow{4}{*}{4.68} & \multirow{4}{*}{$.003^{*}$} & \multirow{4}{*}{$\begin{array}{c}4 \text { ile } 1,2,3 \\
\text { arasinda }\end{array}$} \\
\hline & 2.İyi & 280 & 27.63 & 10.66 & & & \\
\hline & 3. Orta & 343 & 28.30 & 10.64 & & & \\
\hline & 4.Düşük & 62 & 33.13 & 10.97 & & & \\
\hline \multirow{3}{*}{$\begin{array}{l}\text { Sosyal } \\
\text { medya }\end{array}$} & 1.Çok İyi & 91 & 36.01 & 10.63 & \multirow{3}{*}{1.81} & \multirow{3}{*}{.144} & \multirow{3}{*}{ Yok } \\
\hline & 2.İyi & 280 & 38.10 & 10.55 & & & \\
\hline & 3. Orta & 343 & 36.65 & 11.31 & & & \\
\hline
\end{tabular}




\begin{tabular}{|c|c|c|c|c|c|c|c|}
\hline & 4.Düşük & 62 & 38.97 & 11.03 & & & \\
\hline & 1.Çok İyi & 91 & 17.34 & 5.82 & \multirow{4}{*}{4.37} & \multirow{4}{*}{$.005^{*}$} & \multirow{4}{*}{4 ile 2 arasında } \\
\hline Günlük & 2.İyi & 280 & 15.44 & 6.05 & & & \\
\hline \multirow[t]{2}{*}{ hayata etkisi } & 3.Orta & 343 & 16.31 & 6.23 & & & \\
\hline & 4.Düşük & 62 & 18.10 & 7.14 & & & \\
\hline
\end{tabular}

${ }^{*} \mathrm{p}<.05$

Tablo 6' da yer alan veriler incelendiğinde ortaöğretim düzeyinde öğrenim görmekte olan öğrencilerin dijital bağımlılıklarının ölçeğin toplamı, oyun ve günlük hayat etkisi faktörlerinde anlamlı farklılık gösterdiği $\mathrm{p}<.05$; sosyal medya faktöründe ise göstermediği p>.05 saptanmıştır. Anlamlı farklılığın hangi gruplar arasında olduğunun tespiti amacıyla uygulanan TUKEY analizine göre; toplam puanda "Düşük ile İi, Orta" grupları arasında düşük aleyhine; oyun faktöründe "Düşük ile Çok iyi, Iyi, Orta" grupları arasında düşük aleyhine; günlük hayata etkisi faktöründe "Düşük ile İyi" grupları arasında düşük aleyhine olmak üzere farklılık belirlenmiştir. Toplam puan açısından ele alındığında en yüksek puan ortalamasına sahip öğrencilerin ekonomik durumu düşük öğrencilere en yüksek puan ortalamasına ise ekonomik durumu iyi olan öğrencilerin sahip oldukları tespit edilmiştir.

Ortaöğretim öğrencilerinin şiddet eğilimlerine ilişkin puan ortalamalarının ekonomik durum değişkenine göre anlamlı şekilde farklılık gösterip göstermediğinin belirlenmesi amaciyla uygulanan ANOVA testi bulgularına Tablo 7' de yer verilmektedir.

Tablo 7. Ekonomik durum değişkenine göre şiddet eğilimleri ANOVA testi bulguları

\begin{tabular}{|c|c|c|c|c|c|c|c|}
\hline & $\begin{array}{l}\text { Ekon. } \\
\text { Dur. }\end{array}$ & $\mathbf{N}$ & $\bar{x}$ & ss & F & $\mathrm{p}$ & TUKEY \\
\hline \multirow{4}{*}{ Toplam } & 1.Çok İyi & 91 & 37.24 & 8.18 & \multirow{4}{*}{.99} & \multirow{4}{*}{.398} & \multirow{4}{*}{ Yok } \\
\hline & 2.İyi & 280 & 35.75 & 7.89 & & & \\
\hline & 3.Orta & 343 & 36.49 & 7.96 & & & \\
\hline & 4.Düşük & 62 & 36.73 & 7.80 & & & \\
\hline \multirow{4}{*}{$\begin{array}{l}\text { Şiddet } \\
\text { duygusu }\end{array}$} & 1.Çok İyi & 91 & 10.81 & 3.04 & \multirow{4}{*}{1.95} & \multirow{4}{*}{.121} & \multirow{4}{*}{ Yok } \\
\hline & 2.İyi & 280 & 10.11 & 2.80 & & & \\
\hline & 3.Orta & 343 & 10.35 & 2.85 & & & \\
\hline & 4.Düşük & 62 & 10.79 & 2.86 & & & \\
\hline \multirow{4}{*}{$\begin{array}{l}\text { Bilişim } \\
\text { şiddeti }\end{array}$} & 1.Çok İyi & 91 & 7.25 & 1.96 & \multirow{4}{*}{.055} & \multirow{4}{*}{.983} & \multirow{4}{*}{ Yok } \\
\hline & 2.İyi & 280 & 7.17 & 1.88 & & & \\
\hline & 3.Orta & 343 & 7.21 & 1.75 & & & \\
\hline & 4.Düşük & 62 & 7.19 & 1.97 & & & \\
\hline \multirow{4}{*}{$\begin{array}{l}\text { Zarar verme } \\
\text { düşüncesi }\end{array}$} & 1.Çok İyi & 91 & 9.22 & 2.58 & \multirow{4}{*}{1.35} & \multirow{4}{*}{.258} & \multirow{4}{*}{ Yok } \\
\hline & 2.İyi & 280 & 8.65 & 2.34 & & & \\
\hline & 3.Orta & 343 & 8.86 & 2.55 & & & \\
\hline & 4.Düşük & 62 & 8.97 & 2.57 & & & \\
\hline \multirow{4}{*}{$\begin{array}{l}\text { Şiddet } \\
\text { uygulama }\end{array}$} & 1.Çok İyi & 91 & 9.96 & 2.42 & \multirow{4}{*}{.60} & \multirow{4}{*}{.614} & \multirow{4}{*}{ Yok } \\
\hline & 2.İyi & 280 & 9.83 & 2.51 & & & \\
\hline & 3.Orta & 343 & 10.07 & 2.46 & & & \\
\hline & 4.Düşük & 62 & 9.77 & 2.00 & & & \\
\hline
\end{tabular}


Tablo 7'deki bulgular analiz edildiğinde ortaöğretim öğrencilerinin şiddet eğilimleri üzerinde ekonomik durum değişkeninin ölçeğin toplamı ve tüm faktörlerinde belirleyici bir farklılık oluşturmadığı p>.05 saptanmıştır. Ölçeğin toplam puan ortalamasına bakıldığında en yüksek puanı ekonomik durumunu çok iyi olarak ifade eden grubun en düşük puanı ise ekonomik durumunu iyi olarak ifade eden grubun aldığı görülmektedir.

Ortaöğretim öğrencilerinin dijital bağımlılıklarına yönelik puan ortalamalarının anne eğitim durumu değişkenine göre anlamlı şekilde farklılık gösterip göstermediğinin belirlenmesi amacıyla uygulanan ANOVA testi bulgularına Tablo 8' de sunulmaktadır.

Tablo 8. Anne eğitim durumu değişkenine göre dijital bağımlıkları ANOVA testi bulguları

\begin{tabular}{|c|c|c|c|c|c|c|c|}
\hline & Anne Eğit. & $\mathbf{N}$ & $\bar{x}$ & ss & $\mathbf{F}$ & $\mathbf{p}$ & $\begin{array}{c}\text { Anlamlı Fark } \\
\text { TUKEY }\end{array}$ \\
\hline \multirow{4}{*}{ Toplam } & 1.İlkokul & 305 & 83.20 & 22.73 & \multirow{4}{*}{2.47} & \multirow{4}{*}{.060} & \multirow{4}{*}{ Yok } \\
\hline & 2.Ortaokul & 227 & 78.62 & 21.54 & & & \\
\hline & 3.Lise & 158 & 83.51 & 22.70 & & & \\
\hline & 4.Üniversite & 86 & 83.84 & 21.77 & & & \\
\hline \multirow{4}{*}{ Oyun } & 1.İlkokul & 305 & 28.86 & 10.71 & \multirow{4}{*}{2.57} & \multirow{4}{*}{.053} & Yok \\
\hline & 2.Ortaokul & 227 & 26.93 & 10.18 & & & \\
\hline & 3.Lise & 158 & 28.89 & 11.14 & & & \\
\hline & 4.Üniversite & 86 & 30.19 & 9.99 & & & \\
\hline \multirow{4}{*}{$\begin{array}{l}\text { Sosyal } \\
\text { medya }\end{array}$} & 1.İlkokul & 305 & 37.56 & 10.86 & \multirow{4}{*}{1.07} & \multirow{4}{*}{.361} & Yok \\
\hline & 2.Ortaokul & 227 & 36.32 & 10.95 & & & \\
\hline & 3.Lise & 158 & 38.25 & 10.93 & & & \\
\hline & 4.Üniversite & 86 & 37.08 & 11.33 & & & \\
\hline \multirow{4}{*}{$\begin{array}{l}\text { Günlük } \\
\text { hayata } \\
\text { etkisi }\end{array}$} & 1.İlkokul & 305 & 16.79 & 6.36 & \multirow{4}{*}{2.38} & \multirow{4}{*}{$.048^{*}$} & \multirow{4}{*}{1 ile 2 arasınd } \\
\hline & 2.Ortaokul & 227 & 15.37 & 6.12 & & & \\
\hline & 3.Lise & 158 & 16.37 & 6.30 & & & \\
\hline & 4.Üniversite & 86 & 16.57 & 5.81 & & & \\
\hline
\end{tabular}

$\mathrm{p}<.05^{*}$

Tablo 8'de yer alan ortaöğretim öğrencilerinin dijital bağımlılıklarının anne eğitim durumu değişkeni açısından analizine ilişkin bulgular incelendiğinde; ölçeğin toplamı, oyun ve sosyal medya faktörleri açısından anlamlı farklılık olmadığı, günlük hayata etkisi faktöründe ise "ilkokul ile Ortaokul" arasında ilkokul aleyhine olmak üzere anlamlı farklılık bulunduğu tespit edilmiştir. Toplam puana göre en yüksek puana sahip grubun annesi üniversite mezunu, en düşük puana ise annesi ortaokul mezunu olan grubun sahip olduğu belirlenmiştir. 
Ortaöğretim öğrencilerinin şiddet eğilimlerinin anne eğitim durumu değişkenine göre anlamlı şekilde farklılık gösterip göstermediğinin belirlenmesi amacıyla uygulanan ANOVA testi bulgularına Tablo 9'da yer verilmektedir.

Tablo 9. Anne eğitim durumu değişkenine göre şiddet eğilimleri ANOVA testi bulguları

\begin{tabular}{|c|c|c|c|c|c|c|c|}
\hline & Anne Eğit. & $\mathbf{N}$ & $\overline{\mathrm{x}}$ & ss & $\mathbf{F}$ & p & $\begin{array}{c}\text { Anlamlı Fark } \\
\text { TUKEY }\end{array}$ \\
\hline \multirow{4}{*}{ Toplam } & 1.İlkokul & 305 & 35.80 & 7.78 & \multirow{4}{*}{2.91} & \multirow{4}{*}{$.034^{*}$} & \multirow{4}{*}{$\begin{array}{l}1 \text { ile 3, } 4 \text { arasınd } \\
2 \text { ile 3, } 4 \text { arasind }\end{array}$} \\
\hline & 2.Ortaokul & 227 & 35.72 & 7.58 & & & \\
\hline & 3.Lise & 158 & 37.69 & 8.75 & & & \\
\hline & 4.Üniversite & 86 & 37.33 & 7.65 & & & \\
\hline \multirow{4}{*}{$\begin{array}{l}\text { Şiddet } \\
\text { duygusu }\end{array}$} & 1.İlkokul & 305 & 10.21 & 2.87 & \multirow{4}{*}{1.84} & \multirow{4}{*}{.138} & \multirow{4}{*}{ Yok } \\
\hline & 2.Ortaokul & 227 & 10.25 & 2.72 & & & \\
\hline & 3.Lise & 158 & 10.83 & 3.10 & & & \\
\hline & 4.Üniversite & 86 & 10.27 & 2.69 & & & \\
\hline \multirow{4}{*}{$\begin{array}{l}\text { Bilişim } \\
\text { şiddeti }\end{array}$} & 1.İlkokul & 305 & 7.03 & 1.79 & \multirow{4}{*}{2.95} & \multirow{4}{*}{$.032^{*}$} & \multirow{4}{*}{1 ile 3 arasında } \\
\hline & 2.Ortaokul & 227 & 7.12 & 1.84 & & & \\
\hline & 3.Lise & 158 & 7.53 & 1.92 & & & \\
\hline & 4.Üniversite & 86 & 7.38 & 1.76 & & & \\
\hline \multirow{4}{*}{$\begin{array}{l}\text { Zarar } \\
\text { verme } \\
\text { düşünces } \\
\text { i }\end{array}$} & 1.İlkokul & 305 & 8.81 & 2.36 & \multirow{4}{*}{1.26} & \multirow{4}{*}{.287} & \multirow{4}{*}{ Yok } \\
\hline & 2.Ortaokul & 227 & 8.63 & 2.48 & & & \\
\hline & 3.Lise & 158 & 9.06 & 2.71 & & & \\
\hline & 4.Üniversite & 86 & 9.08 & 2.46 & & & \\
\hline \multirow{4}{*}{$\begin{array}{l}\text { Şiddet } \\
\text { uygulam } \\
\text { a }\end{array}$} & 1.İlkokul & 305 & 9.75 & 2.33 & \multirow{4}{*}{4.32} & \multirow{4}{*}{$.005^{*}$} & \multirow{4}{*}{4 ile 1,2 arasınd } \\
\hline & 2.Ortaokul & 227 & 9.73 & 2.27 & & & \\
\hline & 3.Lise & 158 & 10.28 & 2.67 & & & \\
\hline & 4.Üniversite & 86 & 10.59 & 2.63 & & & \\
\hline
\end{tabular}

${ }^{*} \mathrm{p}<.05$

Tablo 9'daki bulgular analiz edildiğinde ortaöğretim öğrencilerinin şiddet eğilimleri ölçeğinden aldıkları puan ortalamalarının anne eğitim durumu değişkenine göre ölçeğin toplamı, bilişim teknolojileri aracılığıyla şiddet, başkalarına şiddet uygulama faktörlerinde anlamlı farklılık gösterdiği p<.05, şiddet duygusu, başkalarına zarar verme düşüncesi faktörlerinde anlamlı farklılık göstermediği p>.05 belirlenmiştir. Anlamlı farklılığın hangi gruplar arasında olduğunun belirlenmesi amacıyla uygulanan TUKEY analizine göre ölçeğin toplamında "Illkokul ile Lise, Üniversite" arasında ilkokul lehine, "Ortaokul ile Lise, Üniversite" arasında ortaokul lehine; bilişim teknolojileri aracılığıyla şiddet faktöründe "ílkokul ile Lise", arasında ilkokul lehine; başkalarına şiddet uygulama faktöründe "Üniversite ile İlkokul, Ortaokul" arasında üniversite aleyhine anlamlı farklılığı oluştuğu bulgusuna ulaşılmıştır. Öğrencilerin aldıkları puan ortalamaları toplam puan açısından değerlendirildiğinde; en 
yüksek puan ortalamasına annesi lise, en düşük annesi ortaokul mezunu olan gruplara ait olduğu belirlenmiştir.

Ortaöğretim öğrencilerinin dijital bağımlılıklarına yönelik puan ortalamalarının baba eğitim durumu değişkenine göre anlamlı şekilde farklılık gösterip göstermediğinin belirlenmesi amaciyla uygulanan ANOVA testi bulgularına Tablo 10' da sunulmaktadir.

Tablo 10. Baba eğitim durumu değişkenine göre dijital bağımlıkları ANOVA testi bulguları

\begin{tabular}{|c|c|c|c|c|c|c|c|}
\hline & Baba Eğit. & $\mathbf{N}$ & $\bar{x}$ & ss & F & p & $\begin{array}{c}\text { Anlamlı Fark } \\
\text { TUKEY }\end{array}$ \\
\hline \multirow{4}{*}{ Toplam } & 1.İlkokul & 170 & 84.18 & 22.95 & \multirow{4}{*}{1.68} & \multirow{4}{*}{.170} & \multirow{4}{*}{ Yok } \\
\hline & 2.Ortaokul & 171 & 81.69 & 21.97 & & & \\
\hline & 3.Lise & 253 & 79.72 & 22.75 & & & \\
\hline & 4.Üniversite & 182 & 83.41 & 21.38 & & & \\
\hline \multirow{4}{*}{ Oyun } & 1.İlkokul & 170 & 29.82 & 11.10 & \multirow{4}{*}{2.55} & \multirow{4}{*}{.055} & \multirow{4}{*}{ Yok } \\
\hline & 2.Ortaokul & 171 & 28.00 & 10.88 & & & \\
\hline & 3.Lise & 253 & 27.23 & 10.26 & & & \\
\hline & 4.Üniversite & 182 & 29.27 & 10.19 & & & \\
\hline \multirow{4}{*}{$\begin{array}{l}\text { Sosyal } \\
\text { medya }\end{array}$} & 1.İlkokul & 170 & 37.81 & 10.72 & \multirow{4}{*}{.67} & \multirow{4}{*}{.569} & \multirow{4}{*}{ Yok } \\
\hline & 2.Ortaokul & 171 & 37.04 & 10.59 & & & \\
\hline & 3.Lise & 253 & 36.63 & 11.15 & & & \\
\hline & 4.Üniversite & 182 & 37.93 & 11.26 & & & \\
\hline \multirow{4}{*}{$\begin{array}{l}\text { Günlük } \\
\text { hayata } \\
\text { etkisi }\end{array}$} & 1.İlkokul & 170 & 16.54 & 6.79 & \multirow{4}{*}{.54} & \multirow{4}{*}{.544} & \multirow{4}{*}{ Yok } \\
\hline & 2.Ortaokul & 171 & 16.66 & 6.31 & & & \\
\hline & 3.Lise & 253 & 15.85 & 6.23 & & & \\
\hline & 4.Üniversite & 182 & 16.20 & 5.61 & & & \\
\hline
\end{tabular}

$\mathrm{p}<.05^{*}$

Tablo 10 incelendiğinde; ortaöğretim öğrencilerinin dijital bağımlılıklarının baba eğitim durumu değişkeni açısından ölçeğin toplamı ve tüm faktörleri açısından anlamlı farklılık olmadığ 1 p $>.05$ tespit edilmiştir. Toplam puana göre en yüksek puana sahip grubun babası ilkokul mezunu, en düşük puana ise babası lise mezunu olan grubun sahip olduğu belirlenmiştir.

Ortaöğretim öğrencilerinin şiddet eğilimlerinin baba eğitim durumu değişkenine göre anlamlı şekilde farklılık gösterip göstermediğinin belirlenmesi amacıyla uygulanan ANOVA testi bulgularına Tablo 11'de yer verilmektedir. 
Tablo 11. Eğitim durumu değişkenine göre şiddet eğilimleri ANOVA testi bulguları

\begin{tabular}{|c|c|c|c|c|c|c|c|}
\hline & $\begin{array}{l}\text { Baba } \\
\text { Eğit. }\end{array}$ & $\mathbf{N}$ & $\overline{\mathrm{x}}$ & ss & $\mathbf{F}$ & $\mathrm{p}$ & $\begin{array}{c}\text { Anlamlı Fark } \\
\text { TUKEY }\end{array}$ \\
\hline \multirow{4}{*}{ Toplam } & 1.İlkokul & 170 & 36.07 & 7.63 & \multirow{4}{*}{2.91} & \multirow{4}{*}{$.034^{*}$} & \multirow{4}{*}{4 ile 2 arasında } \\
\hline & 2.Ortaokul & 171 & 35.53 & 6.97 & & & \\
\hline & 3.Lise & 253 & 35.98 & 8.38 & & & \\
\hline & 4.Üniversite & 182 & 37.81 & 8.34 & & & \\
\hline \multirow{4}{*}{$\begin{array}{l}\text { Şiddet } \\
\text { duygusu }\end{array}$} & 1.İlkokul & 170 & 10.40 & 2.95 & \multirow{4}{*}{1.34} & \multirow{4}{*}{.260} & \multirow{4}{*}{ Yok } \\
\hline & 2.Ortaokul & 171 & 10.23 & 2.60 & & & \\
\hline & 3.Lise & 253 & 10.17 & 2.91 & & & \\
\hline & 4.Üniversite & 182 & 10.69 & 2.93 & & & \\
\hline \multirow{4}{*}{$\begin{array}{l}\text { Bilişim } \\
\text { şiddeti }\end{array}$} & 1.İlkokul & 170 & 7.06 & 1.72 & \multirow{4}{*}{.96} & \multirow{4}{*}{.413} & \multirow{4}{*}{ Yok } \\
\hline & 2.Ortaokul & 171 & 7.13 & 1.84 & & & \\
\hline & 3.Lise & 253 & 7.20 & 1.87 & & & \\
\hline & 4.Üniversite & 182 & 7.38 & 1.89 & & & \\
\hline \multirow{4}{*}{$\begin{array}{l}\text { Zarar } \\
\text { verme } \\
\text { düşüncesi }\end{array}$} & 1.İlkokul & 170 & 8.93 & 2.37 & \multirow{4}{*}{1.01} & \multirow{4}{*}{.387} & \multirow{4}{*}{ Yok } \\
\hline & 2.Ortaokul & 171 & 8.67 & 2.21 & & & \\
\hline & 3.Lise & 253 & 8.72 & 2.63 & & & \\
\hline & 4.Üniversite & 182 & 9.06 & 2.60 & & & \\
\hline \multirow{4}{*}{$\begin{array}{l}\text { Şiddet } \\
\text { uygulama }\end{array}$} & 1.İlkokul & 170 & 9.68 & 2.07 & \multirow{4}{*}{8.33} & \multirow{4}{*}{$.000^{*}$} & \multirow{4}{*}{$\begin{array}{c}4 \text { ile 1, 2, } 3 \\
\text { arasinda }\end{array}$} \\
\hline & 2.Ortaokul & 171 & 9.50 & 2.13 & & & \\
\hline & 3.Lise & 253 & 9.90 & 2.52 & & & \\
\hline & 4.Üniversite & 182 & 10.68 & 2.74 & & & \\
\hline
\end{tabular}

${ }^{*} \mathrm{p}<.05$

Tablo 11'deki verilere göre ortaöğretim öğrencilerinin baba eğitim durumu değişkeni açısından şiddet eğilimlerine ilişkin puan ortalamalarının ölçeğin toplamı ve başkalarına şiddet uygulama faktöründe anlamlı farklılık gösterdiği $p<.05$, diğer faktörler açısından ise anlamlı farklılık göstermediği p>.05 saptanmıştır. Anlamlı farklılı̆̆ın hangi gruplar arasında olduğunun tespiti amacıyla yapılan TUKEY analizine göre ölçeğin toplamında "Üniversite ile Ortaokul" arasında üniversite aleyhine; başkalarına şiddet uygulama faktöründe "Üniversite ile İlkokul, Ortaokul, Lise" arasında üniversite aleyhine olduğu tespit edilmiştir. Ortaöğretim öğrencilerinin şiddet eğilimleri puan ortalamalarına toplam puan açısından bakıldığında; en yüksek puanın babası üniversite mezunu, en düşük puanın ise babası ortaokul mezunu olan öğrencilere ait oldukları belirlenmiştir.

Ortaöğretim öğrencilerinin dijital bağımlılıkları ile şiddet eğilimlerinin toplam puan ve faktörlerine göre aralarındaki korelasyon düzeyinin belirlenmesi amacıyla yapılan Pearson Korelasyon analizi sonuçları Tablo 12' de sunulmuştur. 
Tablo 12. Dijital bağımlılık ile şiddet eğilimleri arasındaki korelasyon testi sonuçları

\begin{tabular}{lccccccccc}
\hline & $\begin{array}{c}\text { Dij. B. } \\
\text { Top. }\end{array}$ & Oyun & $\begin{array}{c}\text { Sos. } \\
\text { Med. }\end{array}$ & $\begin{array}{c}\text { Gün. } \\
\text { Ha. Et. }\end{array}$ & $\begin{array}{c}\text { Şid. Ĕg. } \\
\text { Top }\end{array}$ & $\begin{array}{c}\text { Şiddet } \\
\text { Duy. }\end{array}$ & $\begin{array}{c}\text { Bilişim } \\
\text { Şid. }\end{array}$ & $\begin{array}{c}\text { Baş. Z. } \\
\text { V. D. }\end{array}$ & $\begin{array}{c}\text { Baş. Ş. } \\
\text { U. }\end{array}$ \\
\hline Dij. B. Top. & 1.00 & $.81^{* *}$ & $.86^{* *}$ & $.71^{* *}$ & $.40^{* *}$ & $.34^{* *}$ & $.32^{* *}$ & $.33^{* *}$ & $.32^{* *}$ \\
Oyun & & 1.00 & $.46^{* *}$ & $.37^{* *}$ & $.37^{* *}$ & $.34^{* *}$ & .27 & .29 & $.30^{* *}$ \\
Sos. Med. & & & 1.00 & $.52^{* *}$ & .26 & .19 & .22 & .21 & .24 \\
Gün. Ha. Et. & & & & 1.00 & $.35^{* *}$ & $.33^{* *}$ & .28 & $.32^{* *}$ & .21 \\
Şid. Eğ. Top. & & & & & 1.00 & $.89^{* *}$ & $.83^{* *}$ & $.85^{* *}$ & $.83^{* *}$ \\
Şiddet Duy. & & & & & & 1.00 & $.69^{* *}$ & $.70^{* *}$ & $.48^{* *}$ \\
Bilişim Şid. & & & & & & & 1.00 & $.65^{* *}$ & $.48^{* *}$ \\
Baş. Z. V. D. & & & & & & & & 1.00 & $.45^{* *}$ \\
Baş. Ş. U. & & & & & & & & & 1.00 \\
\hline
\end{tabular}

Tablo 12 incelendiğinde; öğrencilerin dijital bağımlılık toplam puanı ile oyun ( $\mathrm{r}=.81)$, sosyal medya $(\mathrm{r}=.86)$, günlük hayata etkisi $(\mathrm{r}=.71)$ faktörleri arasında pozitif yönde yüksek düzeyde; şiddet eğilimleri toplam puanı $(\mathrm{r}=.40)$, şiddet duygusu ( $\mathrm{r}=.34)$, bilişim teknolojileri ile şiddet $(\mathrm{r}=.32)$, başkalarına zarar verme düşüncesi $(\mathrm{r}=.33)$, başkalarına şiddet uygulama (r=.32) faktörleri arasında pozitif yönde orta düzeyde bir ilişki olduğu belirlenmiştir. Şiddet eğilimleri toplam puanı ile dijital bağımlılık toplam puanı $(\mathrm{r}=.40)$, oyun $(\mathrm{r}=.37)$, günlük hayata etkisi ( $\mathrm{r}=.35)$ arasında pozitif yönde orta düzeyde, sosyal medya $(\mathrm{r}=.26)$ arasında düşük düzeyde; şiddet duygusu ( $(\mathrm{r}=.89)$, bilişim teknolojileri aracılığıyla şiddet ( $\mathrm{r}=.83)$, başkalarına zarar verme düşüncesi $(r=.85)$, başkalarına şiddet uygulama ( $(r=.83)$ faktörleri arasında pozitif yönde yüksek düzeyde bir ilişki olduğu tespit edilmiştir. Toplam puanlar ve faktörler açısından öğrencilerin dijital bağımlılık ve şiddet eğilimlerinin pozitif yönde orta düzeyde bir ilişkinin olduğu görülmektedir. Bu sonuçlar öğrencilerin dijital bağımlılık düzeyleri yükseldikçe şiddete yönelik eğilimlerinin de yükseldiği şeklinde yorumlanabilir.

\section{Tartışma ve Sonuç}

Öğrencilerin dijital bağımlılıklarının ve şiddet eğilimlerinin orta düzeyde olduğu belirlenmiştir. Ortaöğretim öğrencilerinin dijital bağımlılık ölçeğinden aldıkları en yüksek puan ortalamasının sosyal medya en düşük puan ortalamasının ise oyun faktörüne ait olduğu; şiddet eğilimleri ölçeğinden aldıkları puan ortalamalarına göre en yüksek puanı başkalarına şiddet uygulama faktöründe en düşük puanı ise şiddet duygusu faktöründe aldıkları görülmektedir.

Öğrencilerin dijital bağımlılıkları puan ortalamalarının ölçeğin toplamı, günlük hayat etkisi faktöründe erkek, oyun faktöründe kız öğrencilerin aleyhine; şiddet eğilimlerine ilişkin 
puan ortalamalarının cinsiyet değişkeni açısından ölçeğin toplam puanı ve tüm faktörlerinde erkek öğrencilerin aleyhine olmak üzere anlamlı farklılık gösterdiği belirlenmiştir. Dijital bağımlılık ölçeğinin sosyal medya faktöründe ise anlamlı farklılık belirlenememiştir. Gönüç'ün (2009) yaptığı araştırma sonuçlarına bakıldığında kız öğrencilerin dijital bağımlılık düzeylerinin erkek öğrencilere oranla daha düşük düzeyde olduğu tespit edilmiştir. Yine benzer bir sonuç da Eryılmaz ve Çukurluöz (2018) tarafından yapılan araştırmada elde edilmiştir. Arslan'ın (2019) araştırmasında elde edilen sonuçlarda bu çalışmayla uyumluluk göstermektedir. Alan yazında farklı sonuçların elde edildiği araştırmaların bulunduğu belirlenmiştir. Arslan vd.'nin (2015) çalışmasında cinsiyet faktörünün anlamlı farklılık oluşturduğu ancak bu farklılı̆̆ın kız öğrenciler aleyhine olduğu belirlenmiştir. Çam ve Nur (2015) tarafından yapılan çalışmada ise cinsiyet açısından bir farklılık belirlenmemiştir. Ancak dijital bağımlılıkla ilgili yapılan çalışmalara genel olarak bakıldığında erkek öğrencilerin bağımlılık düzeylerinin $\mathrm{k}$ ız öğrencilere oranla daha yüksek olduğu görülmektedir. Bunun nedeni olarak özellikle toplumumuzda erkek çocukların kız çocuklarına nazaran daha az denetime tabi olmaları, sosyal ortamlara girme isteklerinin daha düşük olması dolayısıyla iletişimde sıkıntı yaşamaları, dijital araç gereçlere erişimlerinin nispeten daha erken yaşlarda başlaması, ev dışındaki internet kullanım ortamlarında daha erken yaşlarda bulunmaya başlamaları gösterilebilir.

Öğrencilerin şiddet eğilimleri puan ortalamaları cinsiyet değişkenine göre analiz edildiğinde toplam puan ve tüm faktörlerde kız öğrenciler lehine olmak üzere anlamlı farklılık görülmüştür. Haskan ve Yıldırım'ın (2012) araştırması incelendiğinde bu çalışmayla uyumlu bulgular elde edildiği görülmektedir. Yine Akınsel (2018) tarafından yapılan bir çalışmada da erkek öğrencilerin şiddete daha fazla yönelimlerinin olduğu belirlenmiştir. Erkek öğrencilerin kız öğrencilere oranla iletişim becerilerinin daha geç gelişmesinin duygu, istek ve taleplerini fiziksel güç kullanarak elde etmeye yönelmelerinde etkili olduğu düşünülmektedir. Toplum tarafından erkeğin fiziksel güçle özdeşleştirilmesinin de psikolojileri üzerinde belirli bir düzeyde etkisi olduğu savunulmaktadır. Özellikle erkeklerin duygularını yansıtmamaları gerektiğine ilişkin yaygın kabul sonucunda kendi iç dünyasını yeterince anlatamayan birey yaşadığı içsel mücadeleyle baş edemediğinde çözüm için şiddete yönelmektedir (Avcı \& Yıldırım, 2014).

Ortaöğretim düzeyinde öğrenim gören öğrencilerin dijital bağımlılık düzeylerinin sınıf değişkeni açısından anlamlı farklılık oluşturmadığı bulgusuna ulaşılmıştır. Toplam 
puan açısından değerlendirildiğinde en yüksek puan ortalamasına 11. sınıfta öğrenim gören öğrencilerin en düşük puan ortalamasına ise 12. sınıfta öğrenim gören öğrencilerin sahip oldukları tespit edilmiştir. Gönüç'ün (2009) yaptığı araştırma sonuçlarına göre öğrencilerin dijital bağımlılıklarına ilişkin puan ortalamalarının sınıf düzeyi açısından anlamlı farklılık gösterdiği bulgusuna ulaşılmıştır. En düşük puan ortalamasına sahip grubun on ikinci sınıf öğrencileri en yüksek puan ortalamasına sahip grubun ise dokuzuncu sınıf öğrencileri olduğu tespit edilmiştir. Arslan (2019) tarafından yapılan çalışmada da benzer bulgular elde edilmiştir. Eryılmaz ve Çukurluöz'ün (2018) araştırmasında ise sınıf düzeyinin dijital bağımlılık üzerinde anlamlı farklılık oluşturacak düzeyde bir etkisinin olmadığı saptanmıştır. Bu çalışmada ve diğer çalışmalarda elde edilen sonuçlara bakıldığında ergenliğin özellikle ortaöğretimin ilk sınıflarında daha belirgin etkilerinin görülmesinin sonucunda öğrencilerin bağımlılık düzeylerinin sonraki sınıflara göre daha yüksek olmasında etkisi olduğu düşünülebilir. Bu durum üzerinde öne sürülebilecek gerekçelerden biri de her doğan çocuğun bir öncekine göre daha yoğun dijital araç-gereçlerin kullanıldığ bir ortamı hazır olarak bulmasının sonucunda bu araç-gereçleri daha fazla kullanma eğiliminde olmaları şeklindedir.

Ortaöğretim düzeyinde eğitim alan öğrencilerin şiddet eğilimlerinin sınıf düzeyi değişkeni açısından anlamlı farklılık göstermediği tespit edilmiştir. Toplam puan açısından bakıldığında en yüksek puanın on birinci sınıf öğrencilerine en düşük puanın ise on ikinci sınıf öğrencilerine ait olduğu görülmektedir. Kanal'ın (2008) taptığı araştırma sonuçlarında sınıf düzeyinin öğrencilerinin şiddet eğilimleri üzerinde belirleyici etkisi olduğu bulgusuna ulaşılmıştır. Alt sınıflarda eğitim alan öğrencilerin üst sınıflarda okuyan öğrencilere oranla daha yüksek şiddet eğilimi gösterdiği bulgusuna ulaşılmıştır. Benzer bir bulgu da Arslan ve Konür (2019) tarafından yapılan çalışmada elde edilmiştir. Bu sonuç dijital bağımlılık sonuçlarıyla birlikte değerlendirildiğinde dijital bağımlılığın şiddet eğilimleri üzerinde bir etkisi olabileceği düşünülmektedir. Ayrıca ergenliğin son evreleri olan ortaöğretim ilk sınıflarda öğrencilerin duygularını bastırmakta ve kontrol etmekte üst sınıflarda öğrenim görmekte olan öğrencilere nazaran daha çok zorlanmalarının da önemli olduğu savunulmaktadır.

Ortaöğretim düzeyinde öğrenim görmekte olan öğrencilerin ekonomik durum değişkeni açısından dijital bağımlılık puan ortalamalarının ölçeğin toplamı, oyun ve günlük hayat etkisi faktörlerinde anlamlı farklılık gösterdiği; sosyal medya faktöründe ise 
göstermediği saptanmıştır. Toplam puan açısından ele alındığında en yüksek puan ortalamasına sahip öğrencilerin ekonomik durumu düşük öğrencilere en yüksek puan ortalamasına ise ekonomik durumu iyi olan öğrencilerin sahip oldukları tespit edilmiştir. Kayri ve Günüç (2016) tarafından yapılan çalışma bulgularına göre ekonomik durumu yüksek olan öğrencilerin bağımlılık düzeylerinin de yüksek olduğu belirlenmiştir. Arslan (2019) tarafından ortaöğretim düzeyinde yapılan araştırmada da benzer bulgulara ulaşılmıştır. Ancak alanyazında farklı sonuçların bulunduğu görülmektedir. Arslan vd. (2015) tarafından yapılan araştırmalarda ekonomik durumun dijital bağımlılık üzerinde belirleyici bir etkisinin olmadığı sonucuna ulaşılmıştır.

Araştırmaya katılan öğrencilerin şiddet eğilimleri üzerinde ekonomik durum değişkeninin ölçeğin toplamı ve tüm faktörlerinde belirleyici bir farklılık oluşturmadığı saptanmıştır. Ölçeğin toplam puan ortalamasına bakıldığında en yüksek puanı ekonomik durumunu çok iyi olarak ifade eden grubun en düşük puanı ise ekonomik durumunu iyi olarak ifade eden grubun aldığı görülmektedir. Bu çalışmada anlamlı farklılık tespit edilmemesine karşın ekonomik düzeyi yüksek olan öğrencilerin şiddet eğilimlerinin daha üst düzeyde olması üzerinde düşünülmesi gereken bir noktadır. Bu bağlamda alan yazında yapılan çalışmalar incelendiğinde Arslan ve Konür (2019) tarafından yapılan araştırma sonuçlarında da ortaöğretim öğrencilerinin şiddet eğilimlerinin ekonomik düzey değişkeni açısından anlamlı farklılık gösterdiği ve bu farklılığın yüksek gelir düzeyine sahip aileler aleyhine olduğu belirlenmiştir. Ancak farklı sonuçların elde edildiği çalışmalar da bulunmaktadır. Akınsel'in (2018) yaptığı araştırmaya bakıldığında ise düşük gelirli aileler aleyhine olmak üzere anlamlı farklılık belirlenmiştir.

Ortaöğretim öğrencilerinin dijital bağımlılıklarının anne eğitim durumu değişkeni açısından analizine ilişkin bulgular incelendiğinde; ölçeğin toplamı, oyun ve sosyal medya faktörleri açısından anlamlı farklılık olmadığı, günlük hayata etkisi faktöründe ise anlamlı farklılık bulunduğu tespit edilmiştir. Toplam puana göre en yüksek puana sahip grubun annesi üniversite mezunu, en düşük puana ise annesi ortaokul mezunu olan grubun sahip olduğu belirlenmiştir. Gökçearslan ve Durakoğlu'nun (2014) yaptıkları araştırma bulgularına bakıldığında bu çalışmayla uyumlu olarak daha eğitimli annelerin çocuklarının daha yüksek bağımlılık puan ortalamasına sahip oldukları görülmektedir. Arslan vd.'nin (2015) yaptıkları çalışma sonuçları incelendiğinde ise annesi okuryazar olmayan öğrencilerin diğer öğrencilere göre daha düşük puan ortalamasına sahip oldukları tespit edilmiştir. Arslan 
(2019) tarafından ortaöğretim düzeyinde yapılan bir başka araştırmada yine bu çalışmayla uyumlu sonuçlar elde edilmiştir. Gönüç'ün (2009) çalışmasında ise anne eğitim durumu açısından öğrencilerin bağımlılık puan ortalamalarında anlamlı farklılık bulunmamıştır. Bu sonuçlar oldukça düşündürücüdür. Çünkü genel beklentiler anne eğitim durumu yükseldikçe çocuklara yönelik farkındalığın da artacağı ve zarar verici tutum ve davranışlar konusunda daha etkili mücadele edileceği yönündedir. Bu durumun gerekçelerinin eğitimli annelerin çalışma hayatında daha fazla yer almaları sonucunda çocuklarına yeterince zaman ayırmamaları, onlarla gerektiği kadar ilgilenmemeleri, annenin de çalışma hayatında olmasından dolayı dijital araç-gereçlere daha kolay sahip olunabilmesi olduğu düşünülmektedir.

Çalışmaya dâhil edilen katılımcıların şiddet eğilimleri ölçeğinden aldıkları puan ortalamalarının anne eğitim durumu değişkenine göre ölçeğin toplamı, bilişim teknolojileri aracılığıyla şiddet, başkalarına şiddet uygulama faktörlerinde anlamlı farklılık gösterdiği, şiddet duygusu, başkalarına zarar verme düşüncesi faktörlerinde anlamlı farklılık göstermediği belirlenmiştir. Öğrencilerin aldıkları puan ortalamaları toplam puan açısından değerlendirildiğinde; en yüksek puan ortalamasına annesi lise, en düşük annesi ortaokul mezunu olan gruplara ait olduğu belirlenmiştir. Arslan ve Konür (2019) tarafından ortaöğretim öğrencilerine yönelik çalışmada elde edilen bulgular bu çalışmayla uyumluluk göstermektedir. Eğitimli annelerin çocuklarında şiddet eğiliminin daha yüksek olduğu bulgusu elde edilmiştir. Alanyazında bu sonuçla çelişen araştırmalar da yer almaktadır. Akınsel'in (2018) yaptığı araştırma bulguları incelendiğinde bu çalışmada elde edilen verilerin aksine daha eğitimli annelerin çocuklarının şiddet eğilimlerinin düşük düzeyde olduğu sonucuna ulaşılmıştır. Anne eğitim durumunun yükselmesine paralel olarak öğrencilerin şiddet eğilimlerinin de yükselmesi oldukça önemli bir bulgu olup bunun üzerinde düşünülmesi ve sebeplerinin araştırılması gerekmektedir.

Ortaöğretim öğrencilerinin dijital bağımlılıklarının baba eğitim durumu değişkeni açısından anlamlı farklılık olmadığı tespit edilmiştir. Toplam puana göre en yüksek puana sahip grubun babası ilkokul mezunu, en düşük puana ise babası lise mezunu olan grubun sahip olduğu belirlenmiştir. Gökçearslan ve Durakoğlu (2014) yaptıkları araştırmada baba eğitim durumu yüksek düzeyde olan öğrencilerin puanlarının baba eğitim durumu daha alt düzeyde olan öğrencilerle kıyaslandığında daha yüksek olduğu bulgusuna ulaşmışlardır. Arslan (2019); Arslan vd. (2015) tarafından yapılan çalışmalarda yine baba eğitim durumu 
yüksek olan öğrencilerin dijital bağımlılık ortalamalarının daha yüksek olduğu belirlenmiştir. Gönüç'ün (2009) yaptı̆̆ı araştırmada ise anlamlı farklılık bulunmamıştır. Son dönemlerde yapılan çalışmalar genel olarak değerlendirildiğinde baba eğitim durumunun yüksekliği ile dijital bağımlılık arasında pozitif ilişki bulunduğu görülmektedir. Bunun nedenlerinin gerçekçi bir şekilde ortaya konulması oldukça önemli bulunmaktadır. Baba eğitim durumunun yükselmesinin ailenin ekonomik anlamda daha fazla gelire sahip olmasında önemli olduğu düşünülürse çocuklarında dijital araç-gereçler ve internet erişimlerinin de daha kolay olduğu kabul edilebilir. Baba ve annenin birlikte çalıştığ ailelerde çocuklar genel olarak daha fazla yalnız kalmakta ve teknolojik aletlerle daha fazla zaman geçirmektedir. Çok erken yaşlarda bu araç-gereçlerle tanışan ve bunları kullanmaya başlayan çocuklar özellikle denetim eksikliğinin olmadığı ya da yetersiz olduğu durumlarda dijital bağımlılık yaşayabilmektedir. Çağımızın teknoloji ve bilgi çağı olduğu düşünüldüğünde çocukların erken yaşta bu araç gereçlerle tanışmasının oldukça önemli olduğu kabul edilmekle birlikte denetim konusu oldukça önemlidir. Ayrıca eve gelen yorgun anne ve babaların çocuklarına yeterince vakit ayırmalarının önemli olduğu düşünülmektedir. Ailelerin çocuklarına vakit ayırmalarının yanı sıra onlara yönelik takındıkları ebeveyn tutumları da önemli olmaktadır. Canoğulları'nın (2014) yaptığı araştırma sonuçlarına göre otoriter ebeveynliği benimseyen ailelerin çocuklarında dijital bağımlılık oranının diğerlerine göre daha yüksek olduğu sonucu elde edilmiştir.

Araştırmaya katılan ortaöğretim öğrencilerinin baba eğitim durumu değişkeni açısından şiddet eğilimlerine ilişkin puan ortalamalarının ölçeğin toplamı ve başkalarına şiddet uygulama faktöründe anlamlı farklılık gösterdiği, diğer faktörler açısından ise anlamlı farklılık göstermediği saptanmıştır. Ortaöğretim öğrencilerinin şiddet eğilimleri puan ortalamalarına toplam puan açısından bakıldığında; en yüksek puanın babası üniversite mezunu, en düşük puanın ise babası ortaokul mezunu olan öğrencilere ait oldukları belirlenmiştir. Benzer bir sonuç Arslan ve Konür (2019) tarafından yapılan çalışmada elde edilmiştir. Babası üniversite mezunu olan öğrencilerin en yüksek puan ortalamasına sahip oldukları tespit edilmiştir.

Katılımcıların dijital bağımlılık toplam puanı ile oyun sosyal medya günlük hayata etkisi faktörleri arasında pozitif yönde yüksek düzeyde; şiddet eğilimleri toplam puanı şiddet duygusu, bilişim teknolojileri ile şiddet, başkalarına zarar verme düşüncesi, başkalarına şiddet uygulama faktörleri arasında pozitif yönde orta düzeyde bir ilişki olduğu 
belirlenmiştir. Şiddet eğilimleri toplam puanı ile dijital bağımlılık toplam puanı oyun, günlük hayata etkisi arasında pozitif yönde orta düzeyde, sosyal medya arasında düşük düzeyde; şiddet duygusu, bilişim teknolojileri aracılığıyla şiddet, başkalarına zarar verme düşüncesi, başkalarına şiddet uygulama faktörleri arasında pozitif yönde yüksek düzeyde bir ilişki olduğu tespit edilmiştir. Toplam puanlar ve faktörler açısından öğrencilerin dijital bağımlılık ve şiddet eğilimlerinin pozitif yönde orta düzeyde bir ilişkinin olduğu görülmektedir. Bu sonuçlar öğrencilerin dijital bağımlılık düzeyleri yükseldikçe şiddete yönelik eğilimlerinin de yükseldiği şeklinde yorumlanabilir. Çam ve Nur (2015) tarafından yapılan çalışmada ergenlik dönemindeki öğrencilerin internet bağımlılık düzeyleri depresyon, anksiyete ve obezite oranları arasında anlamlı düzeyde bir ilişki olduğu sonucuna ulaşılmıştır.

Günümüzde teknoloji alanında yaşanılan baş döndürücü gelişme birey ve toplumların hayatında oldukça önemli bir etkiye sahip bulunmaktadır. Farklı alanlarda geliştirilen her türlü araç-gereç hem bireye hem de toplumlara iş hayatından günlük hayata eğitimden iletişime kadar pek çok farklı alanda büyük kolaylıklar sağlamaktadır. Ancak gelişen teknolojinin özellikle iletişim, haberleşme ve eğlence alanlarına yönelik araç-gereç ve ortamlara yönelik bağımlılık yarattığı da belirlenmiştir. Bu bağımlılık kullanılan araçgereçler (telefon, tablet vb.) ve ortamlara (Facebook, instagram vb.) göre farklı adlandırılmakla birlikte dijital bağımlılık adı altında toplanmaktadır. Dijital bağımlılık her yaşta görülmekle birlikte çocuklar ve gençler arasında daha fazla görülmekte, hızla yaygınlaşmakta ve bağımlılık yaşı da gittikçe düşmektedir. Dijital bağımlılık hakkında eğitimcilerin, ailelerin ve bireylerin bilgili ve bilinçli olmaları, kullanılan araç-gereçler ve sosyal ortamların zararlı etkilerini belirlemeye yönelik etkin bir denetim mekanizmasının oluşturulması gerekmektedir. Sosyal ortamlardaki zararlı içeriklere erişimin kısıtlanması ve sanal suç unsurlarına ilişkin caydırıcı cezaların etkin uygulamasının yapılmasının çocuk ve gençlerin geleceği için önemli olduğu düşünülmektedir. Dijital bağımlılık yaşayan bireylerin bağımlılık tedavilerinin yanı sıra bu bireylerde görülen obezite, duruş bozukluğu, göz bozuklukları, kas-iskelet sistemi rahatsızlıkları gibi fiziksel; iletişimsizlik, saplantılı, kaygılı ve asosyal olma gibi toplumsal boyutları olan pek çok alanda yeterli uzmanların bulunduğu tedavi merkezlerinin kurulması gerekmektedir. Eğitim ve sağlık kurumlarının işbirliği kurarak bu konuda toplumu bilinçlendirmesi oldukça önemlidir. Araştırmacıların sadece günümüze görülen olumsuz etkilere yönelik değil gelecekte ortaya çıkabilecek tehlikelere 
yönelik de çalışmalar yapmasının önleyici tedbirlerin alınmasında önemli olduğu düşünülmektedir. Özellikle şiddet içerikli dijital oyunların bireylerin şiddete yönelik eğilimleri üzerindeki etkilerinin nitel ve nicel yöntemler birlikte kullanılarak ve çeşitli yaş kategorilerine yönelik olarak araştırılması gerekmektedir. Şiddet eğilimi ve uygulamasına neden olan bireysel, ailevi, toplumsal nedenleri belirlenmesi ve bu nedenleri azaltacak tedbirlerin alınması oldukça önemli bulunmaktadır. Özellikle çocukların ve ergenlik dönemindeki gençlerin spor, müzik, sanat gibi uğraşlara yönlendirilmesinin hem bağımlılıklar hem de şiddet uygulamalarına yönelik mücadelelerde etkili olduğu kabul edilmektedir. Gençlerin aileleri ve toplum tarafından onaylanması, gerektiğinde tolere edilmesinin onların kendilerini yalnız ve toplumdan dışlanmış hissetmelerinin önüne geçecektir (Avcı \& Yıldırım, 2014). Bu yapılmadığında gençlerin olumsuz özellikteki arkadaş gruplarına ve çetelere katılmaya daha fazla yöneldikleri belirlenmiştir. Özellikle aile ve eğitimcilerin bu konuda dikkatli olmaları büyük önem taşımaktadır (Gül \& Güneş, 2009). Okullarda görev yapan eğitimcilerin ergenlik döneminde yaşanan problemler konusunda bilgi sahibi olmalarının yaşanan olumsuzluklarla başa çıkmalarında yararlı olduğu belirtilmektedir (Arslan, 2018).

\section{Bilgilendirme}

Bu çalışmada kullanılan veriler 2020 yılı öncesine ait olduğu araştırmacı tarafından onaylanmıştır.

\section{Yazar Katkı Beyanı}

Aysel ARSLAN: Kavramsallaştırma, Metodoloji, Veri Toplama ve Analizi, Ön Taslak Yazımı ve Düzenleme, İnceleme-Yazma ve Düzenleme

\section{Kaynaklar}

Akınsel, G. (2018). 15-18 yaş arasındaki ergenlerin şiddet eğilimleri ve dürtüselliklerinin ebeveynlerin sosyo-ekonomik ve okur-yazarlık düzeyi arasındaki ilişki. Yayınlanmamış Yüksek Lisans Tezi. Üsküdar Üniversitesi Sosyal Bilimler Enstitüsü, İstanbul.

Arslan, A. (2018). Ortaokul öğretmenlerinin öğrencilerin ergenlik problemlerine ilişkin kullandıkları çözüm stratejileri. Atatürk Üniversitesi Kazım Karabekir Ĕ̆itim Fakültesi Dergisi, 37, 57-84.

Arslan, A. (2019). Ortaöğretim öğrencilerinin dijital bağımlılık düzeylerinin çeşitli değişkenler açısından incelenmesi (Sivas ili örneği). Gazi Ĕ̆itim Bilimleri Dergisi, 5(2), 63-80. DOI: 10.30855/gjes.2019.05.02.004 
Arslan, A., \& Konür, E. (2019, Nisan). Ortaöğretim öğrencilerinde şiddet eğilimlerinin çeşitli değisskenler açısından incelenmesi. Cumhuriyet 1. Uluslararası Sosyal Bilimler Kongresi, Sivas.

Arslan, A., Kırık, A. M., Karaman, M., \& Çetinkaya, A. (2015). Lise ve üniversite öğrencilerinde dijital bağımlılık. Uluslararası Hakemli Iletişim ve Edebiyat Araştırmaları Dergisi, 8, 34-58.

Avcı, Ö. H., \& Yıldırım, İ. (2014). Ergenlerde şiddet eğilimi, yalnızlık ve sosyal destek. Hacettepe Üniversitesi Ĕ̆itim Fakültesi Dergisi, 29(29-1), 157-168.

Canoğulları, Ö. (2014). Internet bağımlılık düzeyleri farklı ergenlerin cinsiyetlerine göre psikolojik ihtiyaçları, sosyal kaygıları ve anne baba tutum algılarının incelenmesi. Yayınlanmamış Yüksek Lisans Tezi. Çukurova Üniversitesi Sosyal Bilimler Enstitüsü, Adana.

Çam, H. H., \& Nur, N. (2015). Adölesanlarda internet bağımlılı̆̆ı prevalansı ile psikopatolojik semptomlar ve obezite arasındaki ilişkinin incelenmesi. TAF Preventive Medicine Bulletin, 14(3), 181-188. DOI: 10.5455/pmb.20141016033204

Dahlberg, L. L., \& Potter, L. B. (2001). Youth violence: Devolopmental pathways and prevention challenges. American Journal of Prevention Medicine, 20, 3-14.

Davey, L., Day, A., \& Howells, K. (2005). Anger, over-control and serious violent offending. Aggression and Violent Behavior, 10(5), 624-635.

Doğan, U., \& Tosun, H. İ. (2016). Lise öğrencilerinde problemli akıllı telefon kullanımının sosyal kaygı ve sosyal ağların kullanımına aracılık etkisi. Adıyaman Üniversitesi Sosyal Bilimler Enstitüsü Dergisi, 8(22), 99-128. https://doi.org/10.14520/adyusbd.66762

Dursun, Y. (2011). Şiddetin izini sürmek: Şiddet nedir? Felsefe ve Sosyal Bilimler Dergisi, 12, 1-18.

Erkek, N. P. (2016). Yatılı ve gündüzlü eğitim alan ortä̈ğretim öğrencilerinin şiddet eğilimleri ile özgüvenleri arasındaki ilişkinin incelenmesi. Yayınlanmamış Yüksek Lisans Tezi. Gazi Üniversitesi Eğitim Bilimleri Enstitüsü, Ankara.

Eryılmaz, S., \& Çukurluöz, Ö. (2018). Lise öğrencilerinin dijital bağımlılıklarının incelenmesi: Ankara ili, Çankaya ilçesi örneği. Elektronik Sosyal Bilimler Dergisi, 17(67), 889-912.

Gökçearslan, Ş., \& Durakoğlu, A. (2014). Ortaokul öğrencilerinin bilgisayar oyunu bağımlılık düzeylerinin çeşitli değişkenlere göre incelenmesi. Dicle Üniversitesi Ziya Gökalp Ĕ̆itim Fakültesi Dergisi, 23(14), 419-435.

Gönüç, S. (2009). Internet bağımlılık ölçeğinin geliştirilmesi ve bazı demografik değişkenler ile internet bağımlılı̆̆ı arasındaki ilişkilerin incelenmesi. Yayınlanmamış Yüksek Lisans Tezi. Yüzüncü Yıl Üniversitesi Sosyal Bilimler Enstitüsü, Van.

Gül, S. K., \& Güneş, İ. D. (2009). Ergenlik dönemi sorunları ve şiddet. Sosyal Bilimler Dergisi, 11(1), 79-101.

Haskan, Ö., \& Yıldırım, İ. (2012). Şiddet eğilimi ölçeğinin geliştirilmesi. Eğitim ve Bilim, 37(163), 165-177.

Holden, C. (2001). Behavioral' addictions: Do they exist? Science, 294(5544), 980-982.

İldeş, N. (2002). Aile ve şiddet. Radyo ve televizyonda şiddet ve intihar haberlerinin sunumunun toplum üzerindeki etkileri sempozyumu. Ankara: RTÜK Yayınları. 
Kanal, İ. (2008). İmam hatip lisesi öğrencilerinin şiddet eğilimlerinin çok yönlü olarak incelenmesi. Yayınlanmamış Yüksek Lisans Tezi. Yeditepe Üniversitesi Sosyal Bilimler Enstitüsü, İstanbul.

Kayri, M., \& Günüç, S. (2016). Yüksek ve düşük sosyoekonomik koşullara sahip öğrencilerin internet bağımlılı̆̆ı açısından karşılaştırmalı olarak incelenmesi. The Turkish Journal on Addictions, 3(2), 165-183.

Kurupınar, A., \& Erdamar, G. (2014). Ortaöğretim öğrencilerinde görülen madde bağımlılığ1 alışkanlığı ve yaygınlığı: Bartın ili örneği. Sosyal Bilimler Dergisi, 16(1), 65-84.

Marks, I. (1990). Behavioural (non-chemical) addictions. British Journal of Addiction, 85, 13891394.

Page, A., \& İnce, M. (2008). Aile içi şiddet konusunda bir derleme. Türk Psikoloji Yazıları, 11(22), 81-94.

Seo, M., Kang, H. S., \& Yom, Y. (2009). Internet addiction and interpersonal problems in Korean adolescents. CIN: Computers, Informatics, Nursing, 27(4), 226-233.

Sevindik, F. (2011). Fırat üniversitesi öğrencilerinde problemli internet kullanımı ve să̆lıklı yaşam biçimi davranışlarının belirlenmesi. Yayınlanmamış Doktora Tezi. İnönü Üniversitesi Sağlık Bilimleri Enstitüsü, Malatya.

Shine, O., \& Beak, S. (2013). The influence of adolescents smart phone addiction on aggression. Korean Review of Crisis and Emergency Manegement, 9(11), 345-362.

Sparrow, P., \& Griffiths, M. D. (1997). Crime and IT: Hacking and pornography on the internet. Probation Journal, 44, 144-147.

Vural, Z., \& Bat, M. (2010). Yeni bir iletişim ortamı olarak sosyal medya: Ege Üniversitesi iletişim fakültesine yönelik bir araştırma. Journal of Yasar University, 5(20), 3348-3382.

Williams, S., \& Myers, S. (2004). Adolescent violence. The Abfn Journal, 16(2), 31-34.

Yen, J. Y., Yen, C. F., Chen, C. C., Chen, S. H., \& Ko, C. H. (2004). Family factors of internet addiction and substance use experience in Taiwanese adolescents. CyberPsychology $\mathcal{E}$ Behavior, 10(3), 323-329.

JCER's Publication Ethics and Publication Malpractice Statement are based, in large part, on the guidelines and standards developed by the Committee on Publication Ethics (COPE). This article is available under Creative Commons CC-BY 4.0 license (https://creativecommons.org/licenses/by/4.0/) 